Uluslararası Sosyal Bilgilerde Yeni Yaklaşımlar Dergisi, 2021, 5(1), 322-353

International Journal of New Approaches in Social Studies, 2021, 5(1), 322-353

\title{
Sosyal Bilgiler Ders Kitaplarında Yer Alan Bazı İhtilaflı Konu Başlıklarının İncelenmesi
}

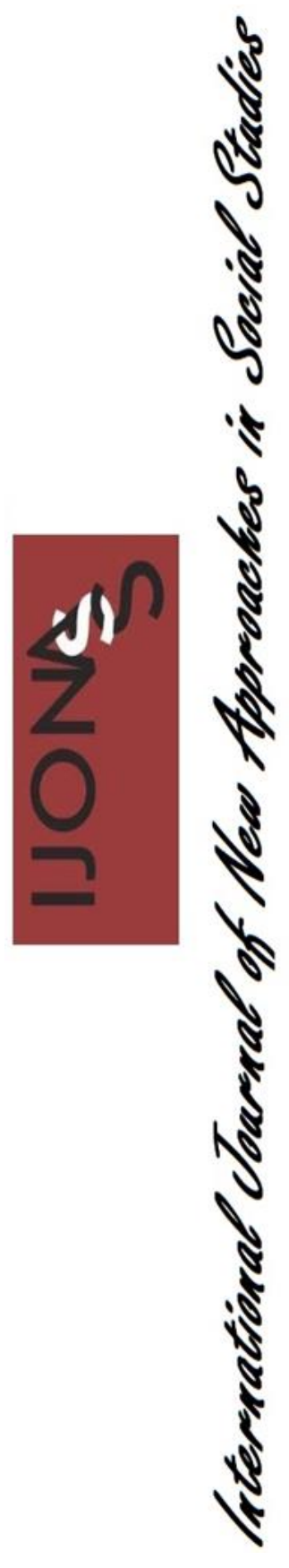

\author{
Mustafa KİRKIT ${ }^{1 *}(\mathbb{D})$ \\ Gönderilme Tarihi: 30 Mart 2021 \\ Kabul Tarihi: 29 Haziran 2021 \\ DOI: $10.38015 /$ sbyy. 905668
}

\begin{abstract}
Öz:
Bu çalışma ihtilaflı konulardan "Bilim” ve alt başlıkları "Yok Olan Türler, Biyoyakıt, İklim Değişikliği, Su Sıkıntısı, Genetiği Değiştirilmiş Organizmaların” sosyal bilgiler ders kitaplarındaki yerini ve dağılımını analiz etmeyi amaçlamıştır. Ihtilaflı konular, bireylerin veya toplumun bir konuda ayrllı̆ga düştüğü, birbirine zıt görüşler ileri sürdüğ̈̈ konular olarak kabul edilebilir. Çalışma da ihtilafl konuların eğitim içerisindeki yeri ve sosyal bilgiler eğitimi alanyazındaki bazı önemli noktalarına da değinilmiştir. Bu çalışmada AB Konseyi'nin ele aldiğı ve Güney INDIANA Üniversitesi'nin belirlediği ihtilaflı konulardan bazılarının içerikteki varlığl, tartışabilirliği ve araştırılan konular hakkında farkındalık oluşturma açısından ele alınmıştır. Araştırmanın kapsamı 2018-2019 yılında Türkiye Cumhuriyeti Milli Eğitim Bakanlı̆̆ onayl okutulan ortaokul 5. 6. ve 7. sinıf sosyal bilgiler ders kitaplarldır. Araştırmanın deseninde nitel araştırma yöntemlerinden doküman incelemesi ve içerik analizi kullanılmıştır. Araştırmanın sonucunda "Bilim" kavramına ders kitaplarında yeterince yer verildiği, alt başlıkların ise yeteri kadar kitaplara yansitılmadiğ tespit edilmiştir. Incelenen ihtilaflı konu başlıkları açısından ögrenci seviyesinin genel olarak gözetildiği söylenebilir. Eksikliği görülen, gelecek nesilleri yakından ilgilendiren "Yok Olan Türler, Biyoyakıt, İklim Değişikliği, Su Sıkıntısı, Genetiği Değiştirilmiş Organizmalar” başlıklarının ögrenciler tarafindan araştırılmasına ve sorgulanmasına firsat tanınabilir. Konuyla ilgili farkındalı̆̆ın artırlması için ders kitaplarında etkinlikler hazırlanabilir. Ders kitaplarında, ihtilaf içeren bu konuların ögrencilerin ilgisini çekmesi ve konu başlıklarının ders sürecine etkin şekilde yansitılması öğretmenin yönlendirmesiyle gerçekleşebilir. İhtilaflı konuların ögretiminde tekrar öğretimde kullanılmak üzere kllavuz kitapların hazırlanarak ögretmeni yönlendirici içeriklerin verilmesi, ihtilaflı konuların daha etkin şekilde ögrenme ortamına yansımasını sağlayabilir. Ihtilaflı konular hakkında alanyazında bazı çalışmaların bulunduğu görülmüştür ancak icelenen araştırma konusunun alanyazında eksikliği görülen bir konu başlı̆̆ olduğu söylenebilir. Bu çalışmanın ise ihtilaflı konularla ilgili hem sosyal bilgiler ĕ̌itimi alanında hem de diğer alanlardaki yapılacak olan bundan sonraki çalışmalara katkı sağlayacă̆ı düşünülmüştür.
\end{abstract}

Anahtar Kelimeler: Sosyal bilgiler, ihtilaflı(tartışmalı) konular, bilim, tartışma, ders kitabl.

\footnotetext{
Abstract:

This study aimed to analyze the place and distribution of controversial issues, such as "Science" and its subtitles "Extinct Species, Biofuels, Climate Change, Water Shortage, Genetically Modified Organisms" in social studies textbooks. The controversial issues can be regarded as issues in which individuals or society differ on an issue and put forward opposing views. In the study, the place of controversial
}

${ }^{1}$ T.C. Adalet Bakanlığı, Türkiye, ORCID ID: 0000-0001-8471-0664

*SorumluYazar (Corresponding Author): mustafakirkit.80@gmail.com 
issues in education and some important points of social studies education in literature are also mentioned. In this study, some of the controversial issues addressed by the EU Council and determined by the Southern INDIANA University are discussed in terms of the content, disputability and raising awareness about the issues under research. The social studies textbooks which are approved by the Ministry of National Education of the Republic of Turkey in 2018-2019 and taught to the 5th, 6th and 7th grades of secondary schools are within the scope of this study. The document analysis which is one of the qualitative research analysis methods and content analysis were used in the design of this research. As a result of the research, it was determined that the concept of "Science" is given enough place in the textbooks, but on the other hand its subtopics are not reflected in the books sufficiently. It can be said that the student level is generally observed in terms of the examined controversial subject headings. Students may be given the opportunity to investigate and question the issues of "Extinct Species, Biofuels, Climate Change, Water Problems, Genetically Modified Organisms", which are lacking and closely related to future generations. Activities can be prepared in textbooks to raise awareness on the subject. These controversial issues in the textbooks can attract the attention of the students and the subject titles can be effectively reflected in the lesson process with the guidance of the teacher. Preparing guidebooks to use for re-teaching of the teaching of controversial subjects and providing teacher-guiding contents can ensure that the controversial issues are reflected in the learning environment more effectively. It has been observed that there are some studies in literature on controversial issues. However, it can be said that the research subject is a topic that is lacking in literature. It was thought that this study would contribute to future studies on controversial issues both in the field of social studies education and in the other fields.

Keywords: Social studies, controversial issues, science, discuss, textbook.

\section{GíRiş}

Birey, yaşam boyu eğitim faaliyetleri sayesinde planlı veya plansız yeni şeyler öğrenmiş ve eğitimsel bir mekanizma olan dünya sistemi içerisinde hayatını sürdürmüştür (Şişman, 2018). $\mathrm{Bu}$ süreçte doğumuyla başlayan eğitim serüveni ölümüne kadar devam etmiş olan birey, toplum içerisinde merak, ilgi alanı, beceri, davranış ve diğer öğretiler gibi birçok sebepten dolayı araştırma yapmaya yönelmiştir. Birey araştırma yaparken, bilinenin üstüne yeni bilişler kazandırmak için bilinmeyeni araştırmış ya da bilinenlere karşı ihtilafta bulunmuştur (Özdemir \& Arslangilay, 2017). Bireyin düşünce, ihtilaf, araştırma, öğrenme gibi yaklaşımlarla yaşamına yenilikler getirmesi ve hayatını daha anlamlı kılma çabasının, toplum yaşamına yenilikler sunduğu söylenebilir. Ayrıca bu süreçlerin hem maddi hem de manevi olarak insanlık tarihine önemli katkılar sunduğu da söylenebilir. Bilim dünyası içerisinde farklı düşünmenin, düşünce özgürlügünün, ihtilaf kültürünün çok ayrı bir önemi olduğu söylenebilir. Hess'e (2005) göre, bilimsel araştırmalar, düşünsel tartışmalar, toplumsal tartışmalar, eğitim, öğretim ve daha birçok konudaki ihtilaf kültürü, bireyin kazanımlarını artırmıştır. İhtilaflı konu; bireylerin düşünce ve görüşlerindeki farklılıklara bağlı olarak ortaya çıkan anlaşmazlıklar ile fikir ayrılığına neden olan konulardır (Manitoba, 2006). Çeşitli kaynaklara bakıldığında ihtilaflı konular; controversial issues, ihtilaf; dispute, disagreement, tartışmal1; controversial, contentious olarak geçmiştiği görülebilir (Y1lmaz, 2012; Ersoy, 2013). Arapça kökenli ve isim köklü bir kavram olan ihtilaf Türk Dil Kurumu'nun tanımında; ayrılık, anlaşmazlık, aykırılık, uyuşmazlık gibi anlamlarla ifade edilmiştir (Türk Dil Kurumu [TDK], 2017). İhtilaflı konuların bilimsel alanyazındaki tanımlarına bakıldığında kelime anlamının geniş çerçevede açıklandığı görülmüştür. İhtilaflı ya da bir diğer ifadeyle tartışmalı konular; toplumu fikir birliğinden ayırarak düşünce konusunda bölen, farklı grupların oluşturduğu uzlaşmaz argümanlar ortaya çıkartan konulardır (Jofre, Kolstrein, Gianella \& Iglesias, 2015). Avaroğulları'na (2015) göre ihtilaflı konular; toplumun geneliyle alakalı olup sabit bir görüşün evrensel olarak sağlanamadığı ve tartışmaya açık olduğu konulardır. Stradling'in (1984) tanımına baktığımızda ihtilaflı konular, çeşitli çözüm önerilerine karşın üzerinde uzlaşılamamış toplumsal ve siyasal konulardır (Akt. Ersoy, 2013, s. 28). Bu tanımlar 
ve alanyazındaki diğer tanımlara bakıldığında ihtilaflı konuların, insanın doğasında yer alan merak duygusunu uyandıran ve düşünmeye yönelten konular olduğu söylenebilir. İnsanın sorular sorması sonucu ortaya çıkan birçok problem ve farklı düşüncelerin, bireyler arasındaki münazarayı başlattığını, bu durumun ise ihtilaflı konuları ortaya çıkardığı söylenebilir. Ayrıca bireyler arasında çoğu zaman ihtilaflı konulardan dolayı değer çatışmaları oluşabilir. $\mathrm{Bu}$ durum aşırılığa kaçmadan düşünce gelişimine katkı sağlayabilir. İnsanların tek tip ve sabit bir düşünce halinde yaşayamayacağı ve bütün konularda uzlaşı, anlaşma sağlanmasının zor olduğu insanlık tarihine bakıldığında görülebilir. Bu yüzden farklılıklar, farklı düşünceler, ihtilaf, insanın bir nevi yaratılışında var olan en temel görünmeyen bir organı kabul edilebilir. Bireyin düşünce gelişimini, becerilerini ve birçok kazanımını etkileyebilecek olan ihtilaf kültürünün erken dönemde verilebileceği temel düzeydeki dersler, sosyal bilgiler dersleri ve müfredata bu konuda eklenecek seçmeli dersler olabilir. Sosyal bilgiler ders içeriklerinde tartışmanın etkin bir şekilde işlenebileceği birçok konu bulunabilir (Öztürk, 2017; MEB, 2018). Bu bağlamda sosyal bilgiler eğitimi içerisinde olan ihtilaflı konu başlıklarının öğretiminin temeli de bu duruma dayandırılabilir.

Her eğitim-öğretim faaliyetinde olduğu gibi sosyal bilgiler derslerinde de en temel ve birincil olarak süreç içerisinde başvurulan kaynak materyal ders kitapları olarak kabul edilebilir. Türkiye'de 2003 yılında hazırlanan "İlköğretimde Ücretsiz Kitap Dağıtımı Projesi" kapsamında ücretsiz dağıtılmaya başlanan ders kitaplarının (Bayrakcı, 2005) öğrenmeye en fazla etki eden unsurlardan birisi olduğu düşünülürse, içeriğinin öğrencilerin çevresi, ilgileri, ihtiyaçları, istekleri, görsel tepkileri, öğrenme düzeyleri, bölgesel durumları, ilgi duyacağı konu başlıkları, aktarımda yer verilmesi gereken güncel içerik ve konular, küresel gelişmeler. Toplumsal konular gibi birçok başlığında etkin bir şekilde verilmesi önemli bir durum olarak görülebilir (Karagözoğlu, 2020). Ayrıca bu konuların içeriği hazırlayan tarafından ders kitaplarında sunulan kısmı tek başına yeterli olarak görülmeyebilir. Ders kitaplarının verimli bir öğrenmeye katkı sağlaması için nitelikli araştırma ve incelemelerle desteklenmesi daha etkin öğrenmeleri sağlayabilir. Bu açıdan çalışmada ele alınan ders kitaplarındaki incelenen ihtilaflı konular içerikle alakalı olan sadece bir konu başlığı olup diğer birçok konu başlığıyla ilgili de çalışma yapılabilir. Alanyazında Sosyal bilgiler ders kitaplarıyla ilgili yapılan çalışmalar incelendiğinde değerlendirme ve inceleme tabanlı çalışmaların (Önal \& Kaya, 2006; Demir \& Atasoy, 2018) olduğu, konu bakımından ise çokkültürlü eğitim (Keskin ve Yaman, 2014), güncel konular (Demirkaya, 2008), vergi bilinci (Yılar \& Çam, 2020), kültürel miras ögeleri (Pehlivan \& Kolaç, 2016), çeşitli değerler (Kuş, Merey \& Karatekin, 2013; Karacan, 2018; Çam, Yılar \& Ünal, 2020), beceriler (Hayırsever \& Kısakürek, 2010; Aydemir, 2017), turizm kavramı (İlhan, Şeker \& Kapıcı, 2015) konularda çalışmaların olduğu görülebilir. Bununla birlikte sosyal bilgiler ders kitaplarını ihtilaflı konular açısından ele alan çalışmaların alanyazında oldukça sınırlı olması ve özellikle araştırma kapsamında ele alınan bilim ve alt başlıklarıyla ilgili çalışmanın kısıtlı olması bu çalışmanın önemini ortaya koyduğu söylenebilir.

Disiplinler arası çalışma alanı olan sosyal bilgiler derslerinin, ihtilaflı konuların öğretiminde önemli bir yerinin olduğu söylenebilir. Soley’ye (1996) göre sosyal bilgiler eğitimi ve öğretiminde ihtilaflı konuların önemi birçok alan eğitmeni tarafından belirtilmiştir. İhtilaflı konuların öğretim aşamasında eğitmenler aşağıdaki verilen maddeler çerçevesinde öğretimi savunmuştur:

- Kalıcı sorular üretmek 
- Müzakere etmeyi öğrenmek

- Farklılıkları yönetme içeriği ve becerisini öğrenmek

- Etkili vatandaşlık için öğrenciyi hazırlamak

- Olumlu karışıklıklar

- Düşünceyi yansitmak

- Değerleri ve farklılıkları anlayan araştırma süreçleri

İhtilaflı konuların birçok alanda çalışma konusu olduğu alanyazında görülebilir (Yazıcı \& Seçgin, 2010; Günal, 2018; Tatar \& Adıgüzel, 2019). Sosyal bilgilerin tanımına baktığımızda ihtilaflı konularla çok fazla ilişkili olan psikoloji, felsefe, sosyoloji, tarih, coğrafya gibi alanlarla ilgili olduğu görülmüştür (Çopur, 2015; Öztürk, 2017). Ayrıca sosyal bilgiler iyi bir vatandaş yetiştirmeyi hedefler. Bu anlamda öğrencilere küçük yaşta demokrasi eğitiminin verildiği sosyal bilgiler, demokratik kazanımların öğretildiği, buna bağlı olarak bireyin üzerine yüklediği hak ve sorumluluklarında erken yaşta verilmek istendiği bir derstir (Safran, 2012). Tartışma kültürünün giderek önem kazandığı günümüzde, erken dönemde verilen derslerden biri olan sosyal bilgiler; ihtilaf, münazara, tartışma, mütabakat sağlama gibi konuların öğrencilere aktarılmasında önemli katkısı olabilir. Bu süreçte ihtilaflı konuları çözmenin yani "Tartışma yapabilmenin temelinde yatan unsurlar ne olabilir?" sorusunun herkes tarafından farklı cevapları olabilir. Alanyazına baktı̆̆ımızda bir tartışmanın olmazsa olmazlarından bazı başlıkların; açık bir şekilde düşünceyi söyleyebilme, üzerinde bir otorite baskısı olmadan düşüncesini açıklayabilme, karşılıklı saygı, farklı düşünceleri ortaya çıkarma, demokratik anlayış gibi başlıklarda toplandığı görülmüştür (Öztürk, 2017).

İhtilaflı konular, düşünce özgürlüğünün olmadığı bir ortamda varolmayabilir. Farklı düşüncelerin açıklanmaması tartışmayı engeller. Bu nedenle eğitim sürecinde tartışmanın etkin ve verimli olması için öğretmenin ayrı bir rolü bulunur. Öğretimin ana aktörü olan öğretmenlerin, ihtilaflı konulara farklı açılardan yaklaştığ düzey öğrenmelere yönlendirdiği söylenebilir (Öztürk, 2017; Yücel, 2018). Hess (2005) öğreticilerin bu yaklaşımlarını şöyle ifade etmiştir:

1- İhtilaflı konunun öğretmen tarafından tartışmalı kabul edilmeyip öğretmen dışındaki çevre tarafından tartışmalı olarak kabul edildiği durumlarda, öğretmen öğrencilere süreç içerisinde düşüncelerini açıklamaktadır. $\mathrm{Bu}$, öğretmene göre nesnel bir yaklaşım kabul edilmektedir. Bunun sonucunda ise öğretmen tartışmalı konunun aslında tartışılmasını sağlamaz ve konunun tartışmalı olmadığını öğretmiş olur.

2- Öğretmenin, toplumun ve öğretim sürecindeki öğrenciler tarafından ihtilaflı olarak kabul edilen konuların tartışılması durumunda öğretmen bir tek bakış açısına yönelip öğrencilerin farklı düşünmelerine engel teşkil ederek konuyu bir düşünceye göre sonuçlandırması, nitelikli tartışma yapılmasını sağlamamaktadır.

3- Öğretmenler, ihtilaflı konuların öğretimine olumlu bakmayabilir. Bunun nedenleri; ögretmen bu konularda kendisini zorlayacak sorulardan çekinebilir, yeteri kadar bilgisi olmayabililir ya da yeterli bilgiye sahip olmasına rağmen öğretim sürecinden buna yer vermek istemeyebilir.

4- Öğretmen ihtilaflı kabul edilen bir konuda farklı düşüncelere ve bakış açılarına nesnel yaklaşabilir ve bu tartışmanın konuların çözümünde, bir uzlaşı ya da denge sağlanmasında önemli bir yeri olduğunu kabul edebilir. 
Amerika Birleşik Devletleri Sosyal Bilgiler Ulusal Konseyi NCSS, (2007) tarafından yayımlanan bildiride ihtilaflı konuların öğretilmesi desteklenerek şu görüşlere yer verilmiştir:

“Tartışmalı (İhtilaflı) konular, tartışma konusunun önceden çözümlendiğine dair bir varsayım olmaksızın veya konuya ilişkin sadece tek bir doğru görüş ve cevap olduğu varsayılmadan sınıfta tartışılmalıdır. Sosyal bilgiler öğretmenleri bu tür konulara eleştirel bir bakış açısıyla yaklaşarak kendi fikirlerinden farklı dahi olsa öğrencilerin çeşitli fikirlerle yüzleşmelerini sağlamalıdır” (Akt. Yılmaz, 2012, s. 203).

$\mathrm{Bu}$ nedenle ihtilaflı konular, sosyal bilgiler derslerinde alan öğretmenleri tarafından daha etkin şekilde sınıf ortamında işlenmeli, gerekirse planlı ve hazırlıklı şekilde sınıf ortamına getirilmelidir. $\mathrm{Bu}$ şekilde işlenen ihtilaflı konular, SBÖP'te yer alan kazanımların ve hedeflenen amaçların gerçekleşmesine katkı sunabilir. Ayrıca öğrencinin problem çözme, yaratıcı düşünme, yansitıcı düşünme, eleştirel düşünme ve karar verme becerisi gibi yetilerine de katkı sunabilir (Avaroğulları, 2015).

İhtilaflı konularla ilgili önemli çalışmaların bulunduğu İndiana Üniversitesi (I.U.B.; 2020), yenilikçi öğretim ve öğrenimin temelinde yer alan konuların içerisinde ihtilaflı konulara da yer verdiği görülmüştür. İhtilaflı konuların öğretimi bazı ders ve disiplinlerin ayrılmaz birer parçası olarak görülmüş, öğretim ve öğrenim sürecinde aktarılan konu başlıklarıyla ilgili güncel tartışmaları da içerisine alan bir anlatımın, iyi yönetilmesi halinde öğrencilerde kalıcılık düzeyinin daha fazla olabileceği belirtilmiştir (Pace, 2003; İ.U., 2020). İhtilaflı konuların sosyal bilgiler öğretiminde daha çok yer verilmesiyse öğrencinin demokratik bakış açısı geliştirme, sosyal adalet, karşıt görüşleri dinleme ve anlama, sorunları keşfederek çözümler getirebilme, birden çok görüşü değerlendirme ve çeşitli perspektifleri anlama, öğrendiklerini daha etkin uygulama gibi bakış açıları ve öğrenimler kazanmasını sağlayabileceği belirtilmiştir (Lockwood, 1996; NCSS, 2020, A.Learner, 2020). Sosyal bilgiler derslerinin erken dönemde bireyin toplumsal bakışını kazanmasına etki edecek birçok konuyu ele alıyor olması, öğrencilere aktarılan bu konuların öğretimini daha kalıcı hale getirebilmeyi önemli bir durum haline getirmiştir (Kirkit, 2019). Konuların öğretiminde yenilikçi yaklaşımların kullanılması da öğrenme-öğretme sürecinde başarıyı sağlayabilir. Özellikle araştırma kapsamında ele alınan ihtilaflı konuların kapsamına bakıldığında sosyal bilgiler öğretiminde ele alınması gereken başlıklar olduğu söylenebilir. Alanyazında ihtilaflı konularla ilgili yapılan bazı çalışmalara bakacak olursak; Avaroğulları (2015) ihtilaflı konular hakkında eylem araştırması kapsamlı bir çalışma yaptığı, Çopur (2015) ihtilaflı konuların öğretimine ilişkin düşünceler hakkında bir çalışma yaptığ 1 , Yılmaz (2012) ihtilaflı konular hakkında öğretmen görüşlerini inceleyen bir çalışma yaptığı görülmüştür. Alanyazında benzer çalışmalar olmakla birlikte araştırma kapsamında ele alınan bilim ve alt başlıklarının ihtilaflı konular içeriği ile sosyal bilgiler kapsamında incelendiği bir çalışmaya rastlanmadığ söylenebilir.

Bu nedenle araştırmada sosyal bilgiler 5. 6. ve 7. sınıf ders kitaplarında tartışmalı(ihtilaflı) konu başlıklarından "Bilim, Yok Olan Türler, Biyoyakıt, İklim Değişikliği, Su Sıkıntısı, Genetiği Değiştirilmiş Organizmaların (GDO)" içerikte nasıl olduğu ve dağılımı analiz edilmeye çalışılmıştır.

\section{Araştırmanın Amacı}

Bu çalışma ihtilaflı konu başlıklarından "Bilim ve alt başlığı olan Yok Olan Türler, Biyoyakıt, İklim Değişikliği, Su Sıkıntısı, Genetiği Değiştirilmiş Organizmaların (GDO)”, 2018/2019 
öğretim yılında MEB onaylı okutulan ortaokul 5. 6. ve 7. sınıf sosyal bilgiler ders kitaplarındaki içeriğine bakılarak analiz edilmesi ve ihtilaflı konu başlıklarının yansımalarının nasıl olduğu, yer aldıkları öğrenme alanları, ünite, konu başlığı analizleri, kullanım sıklığı ve içerikteki durumlarını göstermeyi amaçlamıştır. Çalışmada şu sorulara cevap aranmıştır:

1- Sosyal bilgiler 5. 6. ve 7. sınıf ders kitaplarında tartışmalı(ihtilaflı) konu başlıklarından bilim, yok olan türler, biyoyakıt, iklim değişikliği, su sıkıntısı, genetiği değiştirilmiş organizmalar konu başlıklarının geçtiği öğrenme alanı, ünite başlıklarına dağılımı nasildir?

2- Sosyal bilgiler 5. 6. ve 7. sınıf ders kitaplarında tartışmalı(ihtilaflı) konu başlıklarından bilim, yok olan türler, biyoyakıt, iklim değişikliği, su sıkıntısı, genetiği değiştirilmiş organizmalar konu başlıklarının ders kitaplarında kullanım sıklığı ve yansıması nasıldir?

3- Sosyal bilgiler 5. 6. ve 7. sınıf ders kitaplarında tartışmalı(ihtilaflı) konu başlıklarından bilim, yok olan türler, biyoyakıt, iklim değişikliği, su sıkıntısı, genetiği değiştirilmiş organizmalar konu başlıklarının geçtiği öğrenme alanları ve sınıf düzeylerindeki dağılımının karşılaştırması nasıldır?

\section{Araştırmanın Kapsamı}

Çalışma MEB'in 2018/2019 yılındaki 5. 6. ve 7. sınıflarda okutulan ders kitaplarındaki ihtilaflı konu başlıklarından bilim ve alt başlıkları yok olan türler, biyoyakıt, iklim değişikliği, su sıkıntısı, genetiği değiştirilmiş organizmaların analizini kapsamıştır. Sosyal bilgilerdeki ihtilaflı konu başlıklarının hepsinin bir çalışma içerisinde analizinin zor olması çalışmanın kapsamını sınırlandırmıştır. Araştırma kapsamında incelenen konu başlıkları, sosyal bilgiler alanyazında sınırlı çalışmalar da olması nedeniyle Tablo-1 de yer alan içerikten alanyazına konuyla ilgili farklı çalışmalar kazandırmak için seçilmiştir. Sosyal Bilgiler eğitimi kapsamında ele alınabilecek diğer ihtilaflı konu başlıklarının ise Avrupa Konseyi (2019) göre belirtilen bazı ihtilaflı konu başlıkları olduğu söylenebilir. Bu başlıklar ise aşağıda yer alan Tablo-1 de verilmiştir:

Tablo 1. Bazı İhtilaflı Konu Başlıkları (Avrupa Konseyi, 2019)

\begin{tabular}{ll}
\hline İhtilaflı Konu Başlığı & Alt Konu Başlığı \\
\hline Ekonomi & Yoksulluk, İşsizlik \\
Aile & Boşanma, Evlat Edinme \\
Eğitim & Din Eğitimi, Toplumsal Cinsiyet, Zorunlu Eğitim, Karma Eğitim \\
İstihdam & Asgari Ücret, İşyerinde Ayrımcılık \\
Haklar & Silah Taşıma Serbestliği, Özgür Basın, Hayvan Hakları \\
Etik & İntihar, Klonlama, Avcılık, Kürtaj \\
Din & Elektronik Sağlık Kayıtları, Kimlik Hırsızlığı, İnternet Gizliliği, Elektronik \\
& Harp, Sertifikasız Yazılım Kullanımı \\
Teknoloji & Yaradılış ve Evrim, Şifa ve Din, Kökten dincilik, Terörizm ve Din, Savaş ve \\
Şiddet ve Suç & Din \\
Politika ve Hukuk & Aile İçi Şiddet, Ölüm Cezası, Namus İstismarı, Nefret Suçları, Çocuk \\
Sağlık & İstismarı \\
\hline
\end{tabular}

Araştırmanın kapsamını oluşturan sosyal bilgiler 5. 6. ve 7. sınıf ders kitaplarının künyeleri şu şekildedir: 
- Kitap Adı: Ortaokul ve İmam Hatip Ortaokulu Sosyal Bilgiler Ders Kitabı 5

Kitap Yazarı: Ercan Şahin

Yayınevi: Anadol Yayıncılik

- Kitap Adı: Ortaokul ve İmam Hatip Ortaokulu Sosyal Bilgiler Ders Kitabı 6

Kitap Yazarı: Faruk Gökalp Yılmaz/Hasan Bayraktar/Mustafa Kemal

Özden/Murat Akpınar/Ömer Evin

Yayınevi: MEB

- Kitap Adı: Ortaokul ve İmam Hatip Ortaokulu Sosyal Bilgiler Ders Kitabı 7

Kitap Yazarı: Gökhan Gültekin/Murat Akpınar/Mustafa Nohutcu/Pınar

Özerdoğan/Seher Aygün

Yayınevi: MEB

\section{YÖNTEM}

\section{Araştırmanın Deseni, Veri Toplama ve Veri Analiz Teknikleri}

Araştırma, nitel araştırma yöntemlerinden faydalanılarak desenlenmiştir. Nitel araştırma; veri toplamada nitel tekniklerin kullanılarak, durum, olay, araştırma konusu, alg1 gibi nicelik olarak ölçülmesi, çalışılması zor olan konuları doğal bir şekilde gerçekçi ve bütüncül olarak ele alan, niteliği ön planda tutan bir araştırma sürecidir (Yıldırım \& Şimşek, 2008). Büyüköztürk vd. (2016) nitel araştırmaların genel aşamalarını şöyle sıralamıştır:

- Çalış1lacak olan olayın saptanması

- Çalışmadaki katılımcıların belirlenmesi

- Hipotezlerin üretilmesi

- Verilerin toplanmasi

- Verilerin analizi

Araştırma kapsamında belirlenen ihtilaflı konu başlıklarına doküman incelemesi yapılmıştır. Daha sonra betimsel temelli incelenen ve yorumlanan veriler içerik analizine tabi tutulmuştur. Nitel araştırmalarda sıklıkla kullanılan doküman incelemesi araştırmacının gözlem görüşme gibi uygulamaya dayalı yöntemleri kullanmadan ihtiyaç duyduğu bilgi veya verilere ulaşmasını sağlayan nitel veri toplama tekniğidir (Yıldırım \& Şimşek, 2008). Yıldırım \& Şimşek (2008) doküman incelemesinin aşamalarını dokümanlara ulaşma, orijinalliğini kontrol etme, dokümanları anlama, veriyi analiz etme, veriyi kullanma aşaması olarak belirtmiştir. Nitel araştırma yöntemlerinden içerik analizi esnek bir araştırma yöntemi olan, araştırma yapılırken ulaşılan verileri veya kitap, belge, görsel gibi dokümanları analiz etmek için kullanılan sistematik bir yaklaşım olarak tanımlanmıştır (White \& Marsh, 2006). İçerik analizinin aşamaları ise verilerin kodlanması, temaların bulunması, kodların ve temaların düzenlenmesi, bulguların tanımlanması ve yorumlanması şeklindedir (Yıldırım \& Şimşek, 2008, s. 228-239). Bu kapsamda araştırma soruları çerçevesinde bilim ve alt başlıklar kodları incelenen her bir öğrenme alanında ve ders kitaplarındaki konu başlıklarında temalandırılarak incelenmiştir. Her bir aşamada kategoriler ayrı ayrı ele alınmış, frekanslar oluşturulup nicel verilerle desteklenmeye çalışılmıştır. Bilim başlığında kodlanan veriler örneğin Birey ve Toplum temasında hangi sıklıkta yansıdığı hangi konu başlığında ele alındığ 1 ve içerikteki durumu incelenip, yorumlanmış ve bulgulara ulaşılmıştır. Aynı durum geçerlik ve güvenirlik 
aşamasında da belirtildiği üzere alan uzmanı araştırmacılar tarafından da yapılması istenerek araştırmanın daha nesnel bir çerçeve de sunulması amaçlanmıştır.

\section{Araştırmanın Geçerlik ve Güvenirlik Çalışması}

Araştırma kapsamında geçerliği ve güvenirliği sağlamak için kullanılan nitel yöntemler amaca uygun şekilde uygulanmaya çalışımıştır. Büyüköztürk vd. (2016) göre nitel araştırmalarda güvenirliği arttırmak için araştırmanın her bir aşamasının ve izlenen yolun detaylı bir şekilde tanımlanarak verilmesi, uzman görüşlerine başvurularak elde edilen verilerde tutarlığa bakılması üzerinde durulmalıdır. Bu kapsamda araştırmanın her aşaması açık şekilde verilmiş ve alan uzmanlarından veri toplama ve analiz aşamasında dönüt alınmıştır. 1 eğitim bilim uzmanı, 2 sosyal bilgiler alan uzmanı ve 2 sosyal bilgiler alan öğretmenine araştırma konularından ilgili rastgele başlıkları incelemesi istenmiştir. Araştırma soruları kapsamında belirtilen problemler çerçevesinde uzmanların cevapları istenmiş, verdikleri inceleme ve dönütler elde edilen bulgularla karşılaştırılarak daha verimli bulgu ve yorumlar elde edilmeye çalışılmıştır. Daha sonra uzmanların elde ettikleri veriler, araştırma kapsamında elde edilen verilerle karşılaştırılmış, ayrıca uyuşum yüzdesi de alınmıştır [U.Y.Formülü:Güvenirlik Katsayısı=Görüş birliği Sayısı/(Görüşs Birliği Sayısı+Görüşs Ayrılı̆̆ı Sayısı)x100] (Miles \& Huberman, 1994). Buradaki genel amaç, yanlılığı azaltmak, geçerlik ve güvenirliğin nicel araştırmalara göre daha zor sağlandığı nitel araştırmalardaki durumu en aza indirebilmektir. Miles \& Huberman'a (1994) göre nitel araştırmalarda uyuşum yüzdesi en az 0.80 ve üzeri olursa, araştırmalar daha güvenilir kabul edilebilir. Araştırma kapsamında elde edilen verilere, araştırmada ulaşılan veriler ile uzmanların dönütleri kapsamındaki verilerin karşılaştırılmasıyla ulaşılmış, aynı kodu aynı temada kabul edenler ve farklı kodu farklı temada kabul edenlerin verileri bu karşılaştırmada esas alınmıştır. Araştırma kapsamında elde edilen uyuşum yüzdesi hesaplaması kodlayıcıların görüşleri üzerinden konu başlıkları üzerinde hesaplanmaya çalışılmış, bilim konu başlığındaki görüşler için 0.80 ; yok olan türler konu başlığındaki görüşler için 0.80; GDO konu başlığındaki görüşler için 0.80; biyoyakıt konu başlığındaki görüşler için 1.00; iklim değişikliği başlığındaki görüşler için 1.00; su sıkıntısı başlığındaki görüşler için 1.00 olarak hesaplanmıştır. Ayrıca geçerliği arttırmak için nitel araştırmaların doğasında yer alan araştırmacının düşüncelerinin ve beklentilerinin araştırma sonucuna yansımasını azami seviyeye indirmek için yansız ve ön yargılardan uzak araştırma süreci gerçekleştirilmeye çalışılmıştır. Büyüköztürk vd.'ye (2016) göre bu durum, araştırma konusu üzerinde uzun ve yoğun çalışmalar yapılması, detaylı şekilde tutulan araştırma notları, araştırmaya yansıyabilecek yanlı düşünceleri azaltabilir. Ayrıca elde edilen verilerin dağılım, sıklık, karşılaştırma, tasnif yapılan yerlerinde nitel bulgular tablolarla kısmen nicelleştirilmiştir. Yıldırım ve Şimşek 'e (2008) göre nitel verilerin nicelleştirilesindeki temel amaç geçerlik ve güvenirliği arttırmak, daha objektif veriler elde edebilmektir. Geçerlik ve güvenirliğin sağlanması için araştırma belirtilen aşamalar dikkate alınarak gerçekleştirilmeye çalışılmıştır.

\section{BULGULAR}

Bu bölümde araştırma kapsamında belirlenen alt problemler çerçevesinde araştırmayla ilgili bulgulara yer verilmiştir.

\section{Birinci Alt Probleme Yönelik Bulgular}

Araştırma kapsamında ilk olarak "Sosyal bilgiler 5. 6. ve 7. sınıf ders kitaplarında tartışmalı(ihtilaflı) konu başlıklarından bilim, yok olan türler, biyoyakıt, iklim değişikliği, su sıkıntısı, genetiği değiştirilmiş organizmalar konu başlıklarının geçtiği öğrenme alanı, ünite 
başlıklarına dağılımı nasıldır?” sorusuna cevap aranmıştır. Bu kapsamda sosyal bilgiler ders kitaplarından elde edilen bulgular şu şekilde bulunmuştur:

İncelenen 5. sınıf sosyal bilgiler ders kitaplarında öğrenme alanlarının her biri aynı zamanda ünite ismi olarak verilmiştir. Bu kapsamda birinci soruya yönelik elde edilen bulgulara Tablo2 de bakıldığında 5. sınıf sosyal bilgiler ders kitabında elde edilen bulgular şu şekildedir:

Tablo 2. 5. Sınıf Sosyal Bilgiler Ders Kitabındaki(SBDK) İhtilaflı Konuların Öğrenme Alanı/Ünitelerdeki Başlıklara Yansıması

\begin{tabular}{|c|c|c|c|}
\hline $\begin{array}{c}\text { ÖĞRENME } \\
\text { ALANI/ÜNITE }\end{array}$ & KONU BAŞLIĞI & İHTÍLAFLI KONU & (f) \\
\hline BIREY VE TOPLUM & Sosyal Bilgiler Dersinden Öğrendiklerimiz & Bilim & 1 \\
\hline KÜLTÜR VE MIRAS & Uygarlıkları Öğreniyorum & Bilim & 3 \\
\hline INSANLAR, YERLER VE & İklimin İnsan Faaliyetlerine Etkisi & Bilim & 3 \\
\hline \multirow[t]{3}{*}{ ÇEVRELER } & Nüfus ve Yerleşme & Su Sikıntıs1 & 2 \\
\hline & Afetler ve Çevre Sorunları & İklim Değişikliği & 1 \\
\hline & Doğal Afetlerin Yaşamımıza Etkisi & Yok Olan Türler & 1 \\
\hline BILIM, TEKNOLOJI VE & Neler Öğreneceğiz? & Bilim & 2 \\
\hline \multirow[t]{2}{*}{ TOPLUM } & Bilim İnsanlarının Ortak Özellikleri & Bilim & 23 \\
\hline & Bilimsel Etik & Bilim & 12 \\
\hline ÜRETIM, TÜKETIM VE & Ekonomik Faaliyetler Meslekleri Etkiler & Bilim & 1 \\
\hline \multirow[t]{3}{*}{ DAĞITIM } & Yeni Fikirler Geliştirelim & Bilim & 1 \\
\hline & Ekonomik faaliyerler meslekleri etkiler & GDO & 1 \\
\hline & Çevremizdeki Ekonomik Faaliyetler & $\mathrm{Su}$ Sikıntısı & 4 \\
\hline \multirow[t]{2}{*}{ ETKIN VATANDAŞLIK } & Temel Haklarımızı Öğrenelim & Bilim & 2 \\
\hline & Yaşadığım Yerin Yönetimi & $\mathrm{Su}$ S1k1ntıs1 & 1 \\
\hline$K \ddot{U R E S E L}$ & Ortak Mirasımız & Bilim & 6 \\
\hline \multirow[t]{2}{*}{$B A G L A N T I L A R$} & Yaşadığım Yerin Ülke Ekonomisine Katkısı & Yok Olan Türler & 1 \\
\hline & Afetler ve Çevre Sorunları & Su Sikıntısı & 2 \\
\hline Toplam & & & 67 \\
\hline
\end{tabular}

İncelenen 6. sınıf sosyal bilgiler ders kitaplarında öğrenme alanlarının her biri aynı zamanda ünite ismi olarak verilmiştir. Bu kapsamda birinci soruya yönelik elde edilen bulgulara Tablo3 'te bakıldığında 6 . sınıf sosyal bilgiler ders kitabında elde edilen bulgular şu şekildedir: 
Tablo 3. 6. Sınıf Sosyal Bilgiler Ders Kitabındaki (SBDK) İhtilaflı Konuların Öğrenme Alanı/Ünitelerdeki Başlıklara Yansıması

\begin{tabular}{|c|c|c|c|}
\hline $\begin{array}{c}\text { ÖĞRENME } \\
\text { ALANI/ÜNİTE }\end{array}$ & KONU BAŞLIĞI & $\begin{array}{l}\text { İHTILAFLI } \\
\text { KONU }\end{array}$ & $\mathbf{F}$ \\
\hline BIREY VE TOPLUM & Kültürümüzle Yaşıyor Ve Gelişiyoruz & Bilim & 2 \\
\hline \multirow[t]{4}{*}{ KÜLTÜR VE MIRAS } & İslamiyet' in Doğuşu Ve Değişim & Bilim & 3 \\
\hline & İslamiyet Ve Türkler & Bilim & 10 \\
\hline & Medeniyete Yön Veren Yollar & Bilim & 1 \\
\hline & Destan Ve Yazitlarda Türkler & Su Sikıntısı & 1 \\
\hline INSANLAR, YERLER VE & Ülkemin Zenginlikleri Haritada & Bilim & 1 \\
\hline \multirow[t]{3}{*}{ ÇEVRELER } & Ülkemin Zenginlikleri Haritada & Su Sikıntısı & 2 \\
\hline & Ülkemin Güzellikleri Haritada & İklim Değişikliği & 1 \\
\hline & Neler Öğreneceksiniz? & Bilim & 3 \\
\hline BILIM, TEKNOLOJI VE & Sosyal Bilimler Ve Toplum & Bilim & 71 \\
\hline \multirow[t]{2}{*}{ TOPLUM } & Hayalimdeki Gerçek & Bilim & 20 \\
\hline & Araştırma Yapıyorum & Bilim & 5 \\
\hline ÜRETIM, TÜKETIM VE & Kaynaklarımız Kazanca Dönüşüyor & Bilim & 2 \\
\hline \multirow[t]{7}{*}{$D A \breve{G I T I M}$} & Nitelikli İnsan, Güçlü Türkiye & Bilim & 1 \\
\hline & Mesleğimi Seçiyorum & Bilim & 5 \\
\hline & Dünyamıza Sahip Çıkalım & Yok Olan Türler & 2 \\
\hline & Kaynaklarımız Kazanca Dönüşüyor & Su Sikıntısı & 5 \\
\hline & Dünyamıza Sahip Çıkalım & Su S1kıntıs1 & 3 \\
\hline & Dünyamıza Sahip Çıkalım & İklim Değişikliği & 1 \\
\hline & Dünyamıza Sahip Çıkalım & Biyoyakıt & 2 \\
\hline ETKIN VATANDAŞLIK & Haklarımın Bilincindeyim & Bilim & 2 \\
\hline KÜRESEL BAĞLANTILAR & Komşularımız Ve Kardeşlerimiz & Bilim & 1 \\
\hline Toplam & & & 144 \\
\hline
\end{tabular}

İncelenen 7. sınıf sosyal bilgiler ders kitaplarında öğrenme alanlarının her biri aynı zamanda ünite ismi olarak verilmiştir. Bu kapsamda birinci soruya yönelik elde edilen bulgulara Tablo4'te bakıldığında 7. sınıf sosyal bilgiler ders kitabında elde edilen bulgular şu şekildedir: 
Tablo 4. 7. Sınıf Sosyal Bilgiler Ders Kitabındaki (SBDK) İhtilaflı Konuların Öğrenme Alanı/Ünitelerdeki Bașlıklara Yansıması

\begin{tabular}{|c|c|c|c|}
\hline $\begin{array}{c}\text { ÖĞRENME } \\
\text { ALANI/ÜNITTE }\end{array}$ & KONU BAŞLIĞI & $\begin{array}{l}\text { İHTİLAFLI } \\
\text { KONU }\end{array}$ & $\mathbf{F}$ \\
\hline \multirow[t]{2}{*}{ BIREY VE TOPLUM } & İletişimin Gücü & Bilim & 1 \\
\hline & Hızlı İletişim Güçlü Toplum & Bilim & 2 \\
\hline \multirow[t]{4}{*}{ KÜLTÜR VE MIRAS } & Neler Öğreneceksiniz? & Bilim & 1 \\
\hline & İnsanı Yaşat Ki Devlet Yaşasın & Bilim & 1 \\
\hline & Avrupa'da Uyanış & Bilim & 27 \\
\hline & Değişen Dünyada Değişen Osmanlı & Bilim & 1 \\
\hline INSANLAR YERLER VE & Nereye Yerleşelim? & Su Sikıntıs1 & 1 \\
\hline ÇEVRELER & Tablo Ve Grafiklerle Ülkemiz & Su Sikıntısı & 1 \\
\hline BILLIM, TEKNOLOJI் VE & Neler Öğreneceksiniz? & Bilim & 3 \\
\hline \multirow[t]{5}{*}{ TOPLUM } & Kil Tabletlerden Akıllı Tabletlere & Bilim & 5 \\
\hline & Bilimin Öncüleri & Bilim & 37 \\
\hline & Her Yenilik Geleceğimize Bir Katkıdır & Bilim & 16 \\
\hline & Özgür Düşüncenin Bilime Katkısı & Bilim & 32 \\
\hline & Her Yenilik Geleceğimize Bir Katkıdır & Biyoyakıt & 1 \\
\hline ÜRETIM, TÜKETIM VE & Kaynaklarımız Kazanca Dönüşüyor & Bilim & 2 \\
\hline \multirow[t]{5}{*}{$D A \breve{G I T I M}$} & Üretim Teknolojisi Hayatımızı Etkiliyor & Bilim & 1 \\
\hline & İşinin Ehli İnsan Yetiştirmek & Bilim & 1 \\
\hline & Geleceğin Senin Ellerinde & Bilim & 4 \\
\hline & Vakıf Demek, Medeniyet Demek & İklim Değişikliği & 1 \\
\hline & Geleceğin Senin Ellerinde & GDO & 1 \\
\hline \multirow[t]{9}{*}{ KÜRESEL BAĞLANTILAR } & Türkiye’de Ve Dünyada Barış & Bilim & 2 \\
\hline & Ekonomiye Yön Veren Kuruluşlar & Bilim & 2 \\
\hline & Küresel Sorunlara Çözüm Üretiyorum & Bilim & 1 \\
\hline & Küresel Sorunlara Çözüm Üretiyorum & Biyoyakıt & 1 \\
\hline & Küresel Sorunlara Çözüm Üretiyorum & Su Sikıntısı & 2 \\
\hline & Küresel Sorunlara Çözüm Üretiyorum & İklim Değişikliği & 2 \\
\hline & Küresel Sorunlara Çözüm Üretiyorum & İklim Değişikliği & 7 \\
\hline & Türkiye’de Ve Dünyada Barış & GDO & 1 \\
\hline & Ekonomiye Yön Veren & & 1 \\
\hline Toplam & & & 158 \\
\hline
\end{tabular}

Araştırma kapsamında ders kitaplarında incelenen ihtilaflı konu başlıklarının geçtiği öğrenme alanı ve konu başlıkları yukarıda verildiği şeklindedir. Öğrencilere aktarılan içeriklere bakıldığında 5. 6. ve 7. sınıflarda bilim kavramının çoğu bölümde yer aldığı görülebilir. Bilim kavramı içeriğe yansıtılırken uygun başlıklarla ele alınmıştır. Ayrıca içeriğe yansıtılan konuların öğrenci düzeyine uygun olduğu ve sinıf seviyelerinin de göz önünde bulundurulduğu söylenebilir. Ancak diğer başlıklar bilim kavramı kadar içeriğe yansitılmamıştır.

\section{Íkinci Alt Probleme Yönelik Bulgular}

Araştırma kapsamında ikinci olarak "Sosyal bilgiler 5. 6. ve 7. sınıf ders kitaplarında tartışmalı(ihtilaflı) konu başlıklarından bilim, yok olan türler, biyoyakıt, iklim değişikliği, su sıkıntısı, genetiği değiştirilmiş organizmalar konu başlıklarının ders kitaplarında kullanım sıklığ 1 ve yansıması nasıldır?” sorusuna cevap aranmıştır. Bu kapsamda sosyal bilgiler ders kitaplarından elde edilen bulgular şu şekilde bulunmuştur: 
Tablo 5. 5. Sınıf Sosyal Bilgiler Ders Kitabındaki (SBDK) İhtilaflı Konuların Öğrenme Alanı/Ünitelerdeki Kullanım Siklığı

\begin{tabular}{|c|c|c|c|c|c|c|}
\hline $\begin{array}{l}\text { 5. SINIF } \\
\text { DÜZEYİ }\end{array}$ & Bilim & $\begin{array}{l}\text { Yok Olan } \\
\text { Türler }\end{array}$ & Bivoyakit & $\begin{array}{c}\text { İklim } \\
\text { Deŏjisikliŏji }\end{array}$ & $\mathrm{Sul}_{\mathrm{S}} \mathrm{k}_{\mathrm{k} u \mathrm{t}}^{\mathrm{SS}}$ & Genetiği Değiştirilmiş \\
\hline $\begin{array}{l}\text { Birey ve } \\
\text { Toplum }\end{array}$ & 1 & - & - & - & - & - \\
\hline Kültür ve Miras & 3 & - & - & - & - & - \\
\hline $\begin{array}{l}\text { İnsanlar, Yerler } \\
\text { ve Çevreler }\end{array}$ & 3 & 1(D) & - & 1(D) & $3(\mathrm{D}) / 1$ & - \\
\hline $\begin{array}{l}\text { Bilim, } \\
\text { Teknoloji ve } \\
\text { Toplum }\end{array}$ & 37 & - & - & - & - & - \\
\hline $\begin{array}{l}\text { Üretim, } \\
\text { Tüketim ve } \\
\text { Dağıtım }\end{array}$ & 2 & - & - & - & 4(D) & 1(D) \\
\hline $\begin{array}{l}\text { Etkin } \\
\text { Vatandaşlık }\end{array}$ & 2 & - & - & - & 1(D) & - \\
\hline $\begin{array}{l}\text { Küresel } \\
\text { Bağlantılar }\end{array}$ & 6 & 1(D) & - & - & - & - \\
\hline Toplam (f) & 54 & 2 & & 1 & 9 & 1 \\
\hline
\end{tabular}

Tablo 5'te yer alan veriler sosyal bilgiler 5. sınıf düzeyi ders kitabında araştırma kapsamında incelenen ihtilaflı konu başlıklarının dağılımıdır. Bu kapsamda ihtilaflı konuların kullanım sıklıkları ders kitaplarında incelenmiş, direk kelime olarak geçtiği yerler doğrudan, anlam bakımından yakın fakat kelime olarak kullanılmayan yerlerde dolaylı olarak belirtilmiştir. $\mathrm{Bu}$ kapsamda 5. sınıf SBDK da ele alınan ihtilaflı konulardan en fazla "bilim" başlığının içeriğe yansıdığı, "biyoyakıt" başlığının ise yansıtılmadığı görülmüştür. İçerikte en fazla yer alan "bilim" başlığı öğrenme alanlarından en fazla Bilim Teknoloji ve Toplum başlığında yer almıştır.

Tablo 6. 6. Sınıf SBDK'daki İhtilaflı Konuların Öğrenme Alanı/Ünitelerdeki Kullanım Sıklı̆̆1

\begin{tabular}{lcccccc}
\hline \multicolumn{1}{c}{$\begin{array}{c}\text { 6. SINIF } \\
\text { DÜZEYI }\end{array}$} & Bilim & $\begin{array}{c}\text { Yok Olan } \\
\text { Türler }\end{array}$ & $\begin{array}{c}\text { Biyoyak1 } \\
\text { t }\end{array}$ & $\begin{array}{c}\text { İklim } \\
\text { Değişikliği }\end{array}$ & $\begin{array}{c}\text { Su } \\
\text { Sıkıntısı }\end{array}$ & $\begin{array}{c}\text { Genetiği Değiştirilmiş } \\
\text { Organizmalar }\end{array}$ \\
\hline Birey ve Toplum & 2 & - & - & - & - & - \\
\hline Kültür ve Miras & 14 & - & - & - & $1(\mathrm{D})$ & - \\
\hline $\begin{array}{l}\text { İnsanlar, Yerler } \\
\text { ve Çevreler }\end{array}$ & 1 & - & - & 1 & $2(\mathrm{D})$ & - \\
\hline $\begin{array}{l}\text { Bilim, Teknoloji } \\
\text { ve Toplum }\end{array}$ & 99 & - & - & - & - & - \\
\hline $\begin{array}{l}\text { Üretim, Tüketim } \\
\text { ve Dağıtım }\end{array}$ & 8 & $2(\mathrm{D})$ & 2(D) & $1(\mathrm{D})$ & $8(\mathrm{D})$ & - \\
\hline Etkin Vatandaşlik & 2 & - & - & - & - & - \\
\hline $\begin{array}{l}\text { Küresel } \\
\text { Bağlantılar }\end{array}$ & 1 & - & - & - & - & - \\
\hline Toplam (f) & $\mathbf{1 2 7}$ & $\mathbf{2}$ & $\mathbf{2}$ & $\mathbf{2}$ & $\mathbf{1 1}$ & \\
\hline
\end{tabular}

Tablo 6'da yer alan veriler sosyal bilgiler 6. sınıf düzeyi ders kitabında araştırma kapsamında incelenen ihtilaflı konu başlıklarının dağılımıdır. Bu kapsamda ihtilaflı konuların kullanım sıklıkları ders kitaplarında incelenmiş, direk kelime olarak geçtiği yerler doğrudan, anlam bakımından yakın fakat kelime olarak kullanılmayan yerlerde dolaylı olarak belirtilmiştir. $\mathrm{Bu}$ kapsamda 6. sınıf SBDK'da ele alınan ihtilaflı konulardan en fazla "bilim" başlı̆̆ iç̧eriğe 
yansımıştır. En az seviyede ise "GDO" başlığının olduğu görülmüştür. İçerikte en fazla yer alan "bilim" başlığı öğrenme alanlarından en fazla Bilim Teknoloji ve Toplum başlığında yer almıştır.

Tablo 7. 7. Sınıf SBDK' daki İhtilaflı Konuların Öğrenme Alanı/Ünitelerdeki Dağılımı

\begin{tabular}{|c|c|c|c|c|c|c|}
\hline $\begin{array}{l}\text { 7. SINIF } \\
\text { DÜZEYİ }\end{array}$ & Bilim & $\begin{array}{l}\text { Yok Olan } \\
\text { Türler }\end{array}$ & Biyoyakit & $\begin{array}{c}\text { İklim } \\
\text { Değişikliği }\end{array}$ & $\begin{array}{c}\mathrm{Su} \\
\text { Sikıntıs1 }\end{array}$ & $\begin{array}{c}\text { Genetiği Değiştirilmiş } \\
\text { Organizmalar }\end{array}$ \\
\hline $\begin{array}{l}\text { Birey ve } \\
\text { Toplum }\end{array}$ & 3 & - & - & - & - & - \\
\hline Kültür ve Miras & 30 & - & - & - & - & - \\
\hline $\begin{array}{l}\text { İnsanlar, Yerler } \\
\text { ve Çevreler }\end{array}$ & - & - & - & - & 2(D) & - \\
\hline $\begin{array}{l}\text { Bilim, Teknoloji } \\
\text { ve Toplum }\end{array}$ & 75 & - & $1(\mathrm{D})$ & - & - & - \\
\hline $\begin{array}{l}\text { Üretim, } \\
\text { Tüketim ve } \\
\text { Dağıtım }\end{array}$ & 6 & - & - & 1(D) & - & 1(D) \\
\hline $\begin{array}{l}\text { Etkin } \\
\text { Vatandaşlık }\end{array}$ & - & - & - & - & - & - \\
\hline $\begin{array}{l}\text { Küresel } \\
\text { Bağlantılar }\end{array}$ & 5 & - & 1(D) & $6 / 1(D)$ & 2(D) & 2(D) \\
\hline Toplam (f) & 119 & & 2 & 8 & 4 & 3 \\
\hline
\end{tabular}

Tablo 7'de yer alan veriler sosyal bilgiler 7. sınıf düzeyi ders kitabında araştırma kapsamında incelenen ihtilaflı konu başlıklarının dağılımıdır. Bu kapsamda ihtilaflı konuların kullanım sıklıkları ders kitaplarında incelenmiş, direk kelime olarak geçtiği yerler doğrudan, anlam bakımından yakın fakat kelime olarak kullanılmayan yerlerde dolaylı olarak belirtilmiştir. Bu kapsamda 7. sınıf SBDK' da ele alınan ihtilaflı konulardan en fazla "bilim" başlığının içeriğe yansıdığı, en alt seviyede ise "yok olan türler" başlığının yansıtılmadığı görülmüştür. İçerikte en fazla yer alan "bilim" başlığı öğrenme alanlarından en fazla Bilim Teknoloji ve Toplum başlığında yer almıştır.

Tablo-5, -6 ve -7'de sosyal bilgiler 5. 6. ve 7. sınıf ders kitaplarında geçen ihtilaflı konuların dağılımı doğrudan ve dolaylı olarak geçen bölümleriyle verilmiştir. Kavramlardan bilim başlığı en fazla içerikte "Bilim, Teknoloji ve Toplum” öğrenme alanında yer verilmiştir. MEB (2018) bu öğrenme alanını yayınladığı SBÖP’te şu şekilde açıklamıştır:

"Bu öğrenme alanında öğrencilerden; yenilikçi, eleştirel ve bilimsel düşüncenin bilim ve teknolojideki gelişmelerin temeli olduğunu; bilim ve teknolojinin gelişim sürecini ve toplumsal yaşam üzerindeki etkilerini kavrayarak bilgiye ulaşmada teknolojiyi kullanma becerisi edinmeleri beklenmektedir. Öte yandan, teknolojilerin günlük hayatla ne derecede ilişkili olduğunu öğrenirken bazı teknolojik ürünlerin doğaya verdiği zararları tartışır. Bilimsel eserlerin yasalarla korunduğunu fark ederek akademik dürüstlük ilkelerini dikkate alır."

Sosyal bilgiler ders kitaplarında bilim kavramının en fazla yer verildiği "Bilim, Teknoloji ve Toplum" öğrenme alanında ihtilaflı öğreti olarak ele alınacak yerlerinde ağırlıklı olarak yansıdığı söylenebilir. SBÖP'te yer alan bu öğrenme alanındaki bazı kazanımlara baktığımızda ihtilaflı öğretilere vurgu yapıldığ görülebilir. Bunlar; 5. sınıf SBÖP kazanımlarından "SB.5.4.1. Teknoloji kullanımının sosyalleşme ve toplumsal ilişkiler üzerindeki etkisini tartışır." "SB.5.4.2. Sanal ortamda ulaştığı bilgilerin doğruluk ve 
güvenilirliğini sorgular.", 6. sınıf SBÖP kazanımlarından "SB.6.4.4. Telif ve patent hakları saklı ürünlerin yasal yollardan temin edilmesinin gerekliliğini savunur.", 7. sınıf SBÖP kazanımlarından "SB.7.4.2. Türk-İslam medeniyetinde yetişen bilginlerin bilimsel gelişme sürecine katkılarını tartışır." olduğu söylenebilir (MEB,2018). Buradaki kazanımların ihtilaflı konular üzerinden ele alınması doğal olarak süreç içerisindeki öğretici konumunda olan kişiye düşmektedir. Çünkü kazanımlar her ne kadar tartışmaya yönelik açık ifadeler olsa da süreç içerisinde içeriğin ihtilaflı konular göz önünde bulundurularak işlenmesi gerekebilir. Araştırma kapsamında incelenen ders kitaplarındaki içeriğe bakıldığında ders kitaplarında öğrenme alanı içerisinde verilen değer ve beceriler de ihtilaflı konularla ilişkilendirilerek daha etkili anlatılabilir. Bu durum değer ve beceri öğretimini daha etkin öğretimini de sağlayacaktır (Çopur, 2015). Mesela Dünya'nın düz mü yuvarlak mı olduğu konusunu dönemin şartlarında bilim açısından nasıl bir tartışmalı konu haline geldiğinden yola çıkarak ders sürecinde öğrencilerin zihinsel süreçlerinde konuyla ilgili farklı düşüncelerin varlığını ortaya çıkartmak isteyen bir öğreticinin bunu SBÖP'deki eleştirel düşünme becerisi ve bilimsellik değerinin öğretiminde kullanması bu duruma örnek olarak gösterilebilir. MEB (2018) SBÖP’te verilen öğrenme alanlarında yer alan, "Araştırma, Değişim ve Sürekliliği Algılama, Eleştirel Düşünme, Girişimcilik, İletişim, Kalıp Yargı Ve Önyargıyı Fark Etme, Karar Verme, Medya Okuryazarlığı, Öz Denetim, Yenilikçi Düşünme, Politik Okuryazarlık, Problem Çözme, Sosyal Katılım" becerileriyle ve "Adalet, Barış, Bilimsellik, Dayanışma, Duyarlılık, Dürüstlük, Eşitlik, Özgürlük, Saygı, Sevgi, Sorumluluk, Vatanseverlik, Yardımseverlik" değerleri, ihtilaflı konular kapsamında öğretimle ilişkilendirilebilir. Bu konularda ele alınacak bazı örnekleri güncel ihtilafa düşülen konularından olan din ve bilim arasındaki çekişmeler, çoğalan kitle iletişim araçlarının aile ilikilerini bozması, gıda sektöründeki ürünlerin insan sağlığını bozmaya başladığı hakkındaki görüşler, insanların dünyanın doğal yapısını bozan varlıkların bizzat kendileri olduğu hakkındaki görüşler gibi birçok konu sosyal bilgiler değer ve becerileriyle ilişkilerndirilerek tartışmalı konu başlıkları kapsamında anlatılabilecek örnekler olduğu söylenebilir. Ancak beceri ve değerlerin ders sürecinde öğrenciye sunulmasında, incelenen ders kitapları ve öğretim programında ihtilaflı öğretiler kapsamında ayrıca yer verilmediği görülmüştür. Bu bırakılan boşluk, öğreticinin esneklik kapsamında işleyeceği konular olarak kabul edilebilir.

İhtilaflı bir konu başlığg olan bilimin (Avrupa Konseyi, 2019), içerikte geçen yerlerde tartışma yaratacak ve düşünmeye yönlendirecek şekilde çok az yerde yansitıldığ 1 da söylenebilir. $\mathrm{Bu}$ durum öğretici ders kitabı içerikleri açısından olumsuz yorumlara sebebiyet verebilir. Çünkü bilim ve bilimsel gelişmelerin ilerlemesi için öğrenmenin sorgulama ve eleştirel düşünme tabanlı olması tarihsel süreçte de görüleceği üzere insanlık tarihi açısından olumlu sonuçların oluşmasını sağlamıştır (Küçükali \& Akbaş, 2015). 5. sınıf sosyal bilgiler ders kitabında s.106 da yer alan "Hangi bilim insanlarının isimlerini biliyorsunuz? Bu bilim insanlarının yaptı̆̆ çalışmaların insanlığa katkıları nelerdir?” (Şahin, 2018) 6. sınıf sosyal bilgiler ders kitabında s.121 de yer alan "Sosyal bilimlerin neler olduğunu ögrenecek ve toplum hayatına etkilerine örnekler verebileceksiniz. Bilimsel ve teknolojik gelişmelerin gelecekteki yaşam üzerine etkilerine ilişkin fikirler ileri sürebileceksiniz. Bilimsel araştırma basamaklarını kullanarak araştırma yapmayı ögreneceksiniz." Yine aynı kitapta s. 124 de yer alan "Napolyon'un ve Adolf Hitler'in ordularının yenilmesinde, hangi sosyal bilimler alanı hakkında yeterli bilgiye sahip olmamaları etkili olmuştur? Tartışınız." (Yılmaz, Bayraktar, Özden, Akpınar \& Evin, 2018) 7. sınıf sosyal bilgiler ders kitabındaysa s. 68 de yer alan "Rönesans etkilerini öncelikle sanat daha sonra mimari ve kültürel alanlar aracılığılla göstermiştir. Siz Rönesans Dönemi'nde yaşayan bilim insanı ya da sanatçı olsaydınız hangi alanda çalışmalar yapmak isterdiniz." yine s. 69 da yer alan "Size göre günümüzde bilimin gelişmesinde Aydınlanma 
Çağı'ndaki gelişmelerin nasıl bir etkisi olmuştur? Düşüncelerinizi söyleyiniz.” s. 143 de yer alan "Dünya'nın şekli ile ilgili tartışmalar İlk Çağlara kadar uzanır. İnsanların çoğu Dünya'nın düz olduğu fikrinde iken bazı bilim insanlarl dünyanın yuvarlak olduğunu ispat etmeye çalışmıştır." (Gültekin, Akpınar, Nohutcu, Özerdoğan \& Aygün, 2018) cümleleri bilim kavramıyla ilgili öğretmenin ders kitabı içeriğinde tartışmalı öğretim için yönlendirebileceği bazı örnekler ve içeriğe yansıyan kazanımlar olarak gösterilebilir.

İhtilaflı konu başlıklarından bilim, geniş bir şekilde içeriğe yansımasına karşın diğer başlıkların bilim kadar geniş yansıdığı söylenemez. Özellikle beslenme, gıda güvenliği gibi günümüz de insanın fizyolojik varoluşunu ilgilendiren konularla ilgili olan GDO konusunun, endemik bitkiler ve nesli tükenmekte olan canlılara yönelik bilinç açısından yok olan türler konusunun yenilenebilir enerji, sağlıklı ve yaşama yansıyan kirliliği azaltacak olan biyoyakıt konusunun, küresel bir sorun haline gelen iklim değişikliğinin, öncelikle bölgesel ve gelecekte dünyayı da etkileyebilecek su sıkıntısı konularının sosyal bilgiler ders kitaplarına daha etkin olarak, ihtilaflı konuların muhtevasına uygun tartışmalara yönelik bilgilerle öğrenci düzeyine uygun şekilde içeriğe yansıtılabilir. Sadece sosyal bilgiler ders kitaplarında ihtilaflı konuların yansıtılması tek başına yeterli de olmayabilir.

\section{Üçüncü Alt Probleme Yönelik Bulgular}

Araştırma kapsamında üçüncü olarak "Sosyal bilgiler 5. 6. ve 7. sinıf ders kitaplarında tartışmalı(ihtilaflı) konu başlıklarından bilim, yok olan türler, biyoyakıt, iklim değişikliği, su sıkıntısı, genetiği değiştirilmiş organizmalar konu başlıklarının geçtiği öğrenme alanları ve sınıf düzeylerinde dağılımının karşılaştırması nasıldır?" sorusuna cevap aranmıştır. Bu kapsamda sosyal bilgiler ders kitaplarından elde edilen bulgular şu şekilde bulunmuştur:

Tablo 8. İhtilaflı Konu Başlığı Bilimin Sınıf Düzeylerine Göre Dağılımının Karşılaştırması

\begin{tabular}{lcccc}
\hline \multicolumn{1}{c}{ Öğrenme Alanı } & $\begin{array}{c}\text { 5. Sinıf Ders } \\
\text { Kitabı }\end{array}$ & $\begin{array}{c}\text { 6. Sınıf Ders } \\
\text { Kitabı }\end{array}$ & $\begin{array}{c}\text { 7. Sinıf Ders } \\
\text { Kitabı }\end{array}$ & İhtilaflı Konu \\
\hline Birey ve Toplum & 1 & 2 & 3 & Bilim \\
Kültür ve Miras & 3 & 14 & 30 & Bilim \\
İnsanlar, Yerler ve Çevreler & 3 & 1 & - & Bilim \\
Bilim, Teknoloji ve Toplum & 37 & 99 & 75 & Bilim \\
Üretim, Dağıtım ve Tüketim & 2 & 8 & 6 & Bilim \\
Etkin Vatandaşlık & 2 & 2 & - & Bilim \\
Küresel Bağlantılar & 6 & 1 & 5 & Bilim \\
\hline Toplam & $\mathbf{5 4}$ & $\mathbf{1 2 7}$ & $\mathbf{1 1 9}$ & \\
\hline
\end{tabular}

Tablo 8'de incelenen ihtilaflı konulardan "bilimin" SBDK'ya sınıf düzeyinde yansiyan dağılımına bakıldığında en fazla 6. sınıf SBDK'na 127 yerde yansıdığı görülmüştür. En az ise 5. sınıf SBDK'na 54 yerde yansımıştır. Öğrenme alanı/Ünite olarak bakıldığında her sınıf düzeyleri toplamında en fazla Bilim Teknoloji ve Toplum başlığında yer verilmiş, sınıf düzeyleri arasında ise en fazla 6. sınıf SBDK'daki Bilim Teknoloji ve Toplum Öğrenme Alanı/Ünitesinde 99 yerde yansıdığı görülmüştür. Öğrenme Alanı/Ünite bazında en az yansıdığı başlıklar ise sınıf düzeyleri toplamında İnsanlar, Yerler ve Çevreler ile Etkin Vatandaşlık öğrenme alanlarıdır. Yansıyan tüm kavramlar doğrudan içerikte geçmiştir. 
Tablo 9. İhtilaflı Konu Başlığg1 Yok Olan Türlerin Sınıf Düzeylerine Göre Dağılımının Karşılaştırması

\begin{tabular}{lcccc}
\hline \multicolumn{1}{c}{ Öğrenme Alanı } & $\begin{array}{c}\text { 5. Sinıf Ders } \\
\text { Kitabı }\end{array}$ & $\begin{array}{c}\text { 6. Sinıf Ders } \\
\text { Kitabı }\end{array}$ & $\begin{array}{c}\text { 7. Sinıf Ders } \\
\text { Kitabı }\end{array}$ & İhtilaflı Konu \\
\hline Birey ve Toplum & - & - & - & Yok Olan Türler \\
Kültür ve Miras & - & - & - & Yok Olan Türler \\
İnsanlar, Yerler ve Çevreler & $1(D)$ & - & - & Yok Olan Türler \\
Bilim, Teknoloji ve Toplum & - & - & - & Yok Olan Türler \\
Üretim, Dağıtım ve & - & $2(D)$ & - & Yok Olan Türler \\
Tüketim & - & - & - & Yok Olan Türler \\
Etkin Vatandaşlık & (D) & - & - & Yok Olan Türler \\
Küresel Bağlantılar & $\mathbf{2}$ & $\mathbf{2}$ & - & \\
\hline Toplam & & & & \\
\hline
\end{tabular}

Tablo 9'da incelenen ihtilaflı konulardan "yok olan türlerin” SBDK'ya sınıf düzeyinde yansıyan dağılımına bakıldığında en fazla 5. ve 6. sınıf SBDK'na ikişer yerde yansıdığı görülmüştür. 7. sınıf SBDK hiçbir yerde yansımadığ 1 görülmüştür. Öğrenme alanı/Ünite olarak bakıldığında 6. sınıf düzeyinde en fazla Üretim Dağıtım ve Tüketim başlığında yer verilmiştir. Öğrenme Alanı/Ünite bazında yansımadığı başlıklar ise sınıf düzeyleri toplamında Birey ve Toplum, Kültür ve Miras, Bilim, Teknoloji ve Toplum ile Etkin Vatandaşlık öğrenme alanlarıdır. Yansıyan tüm kavramlar dolaylı olarak içerikte geçmiştir.

Tablo 10. İhtilaflı Konu Başlığgı Biyoyakıtın Sınıf Düzeylerine Göre Dağılımının Karşılaştırması

\begin{tabular}{lcccc}
\hline \multicolumn{1}{c}{ Öğrenme Alanı } & $\begin{array}{c}\text { 5. Sunıf Ders } \\
\text { Kitabı }\end{array}$ & $\begin{array}{c}\text { 6. Sinıf Ders } \\
\text { Kitabı }\end{array}$ & $\begin{array}{c}\text { 7. Sunıf Ders } \\
\text { Kitabı }\end{array}$ & İhtilaflı Konu \\
\hline Birey ve Toplum & - & - & - & Biyoyakıt \\
Kültür ve Miras & - & - & - & Biyoyakıt \\
İnsanlar, Yerler ve Çevreler & - & - & - & Biyoyakıt \\
Bilim, Teknoloji ve Toplum & - & - & $1(D)$ & Biyoyakıt \\
Üretim, Dağıtım ve Tüketim & - & $2(D)$ & - & Biyoyakıt \\
Etkin Vatandaşlık & - & - & - & Biyoyakıt \\
Küresel Bağlantılar & - & - & $1(D)$ & Biyoyakıt \\
\hline Toplam & - & $\mathbf{2}$ & $\mathbf{2}$ & \\
\hline
\end{tabular}

Tablo 10'da incelenen ihtilaflı konulardan "biyoyakıtın" SBDK'ya sınıf düzeyinde yansıyan dağılımına bakıldığında en fazla 6. ve 7. sınıf SBDK'na ikişer yerde yansıdığ 1 görülmüștür. 5 . sınıf SBDK'na hiçbir yerde yansımadığı görülmüştür. Öğrenme alanı/Ünite olarak bakıldığında 6. sınıf düzeyinde en fazla Üretim Dağıtım ve Tüketim başlığında yer verilmiştir. Öğrenme Alanı/Ünite bazında yansımadığı başlıklar ise sınıf düzeyleri toplamında Birey ve Toplum, Kültür ve Miras, İnsanlar, Yerler ve Çevreler ile Etkin Vatandaşlık öğrenme alanlarıdır. Yansıyan tüm kavramlar dolaylı olarak içerikte geçmiştir. 
Tablo 11. İhtilaflı Konu Başlığı İklim Değişikliğinin Sınıf Düzeylerine Göre Dağılımının Karşılaştırması

\begin{tabular}{|c|c|c|c|c|}
\hline Öğrenme Alanı & $\begin{array}{l}\text { 5. Sinıf Ders } \\
\text { KitabI }\end{array}$ & $\begin{array}{l}\text { 6. Sinıf Ders } \\
\text { KitabI }\end{array}$ & $\begin{array}{l}\text { 7. Sinıf Ders } \\
\text { KitabI }\end{array}$ & İhtilaflı Konu \\
\hline Birey ve Toplum & - & - & - & İklim Değişikliği \\
\hline Kültür ve Miras & - & - & - & İklim Değişikliği \\
\hline $\begin{array}{l}\text { İnsanlar, Yerler ve } \\
\text { Çevreler }\end{array}$ & 1(D) & 1 & - & İklim Değişikliği \\
\hline $\begin{array}{l}\text { Bilim, Teknoloji ve } \\
\text { Toplum }\end{array}$ & - & - & - & İklim Değişikliği \\
\hline $\begin{array}{l}\text { Üretim, Dağıtım ve } \\
\text { Tüketim }\end{array}$ & - & 1(D) & 1(D) & İklim Değişikliği \\
\hline Etkin Vatandaşlık & - & - & - & İklim Değişikliği \\
\hline Küresel Bağlantılar & - & - & $6 / 1(\mathrm{D})$ & İklim Değişikliği \\
\hline Toplam & 1 & 2 & 8 & \\
\hline
\end{tabular}

Tablo 11 'de incelenen ihtilaflı konulardan “iklim değişikliğii'nin" SBDK'ya sınıf düzeyinde yansıyan dağılımına bakıldığında en fazla 7. sınıf SBDK'na 8 yerde yansıdı̆̆ı görülmüştür. En az ise 5. sınıf SBDK'na 1 yerde yansımıştır. Öğrenme alanı/Ünite olarak bakıldığında 7. sınıf düzeyinde en fazla Küresel Bağlantılar başlığında yer verilmiştir. Öğrenme Alanı/Ünite bazında yansımadığı başlıklar ise sınıf düzeyleri toplamında Birey ve Toplum, Kültür ve Miras, Bilim, Teknoloji ve Toplum ile Etkin Vatandaşlık öğrenme alanlarıdır. Yansıyan kavramlar 4 yerde dolaylı 7 yerde doğrudan içerikte geçmiştir.

Tablo 12. İhtilaflı Konu Başlığı Su Sıkıntısının Sınıf Düzeylerine Göre Dağılımının Karşılaştırması

\begin{tabular}{lcccc}
\hline \multicolumn{1}{c}{ Öğrenme Alanı } & $\begin{array}{c}\text { 5. Sinıf Ders } \\
\text { Kitabı }\end{array}$ & $\begin{array}{c}\text { 6. Sınıf Ders } \\
\text { Kitabı }\end{array}$ & $\begin{array}{c}\text { 7. Sınıf Ders } \\
\text { Kitabı }\end{array}$ & İhtilaflı Konu \\
\hline Birey ve Toplum & - & - & - & Su Sıkıntısı \\
Kültür ve Miras & - & $1(\mathrm{D})$ & - & Su Sikıntısı \\
İnsanlar, Yerler ve Çevreler & $3(\mathrm{D}) / 1$ & $2(\mathrm{D})$ & $2(\mathrm{D})$ & Su Sıkıntısı \\
Bilim, Teknoloji ve Toplum & - & - & - & Su Sikıntısı \\
Üretim, Dağıtım ve Tüketim & $4(\mathrm{D})$ & $8(\mathrm{D})$ & - & Su Sıkıntısı \\
Etkin Vatandaşlık & $1(\mathrm{D})$ & - & - & Su Sikıntısı \\
Küresel Bağlantılar & - & - & $2(\mathrm{D})$ & Su Sikıntıs1 \\
\hline Toplam & $\mathbf{9}$ & $\mathbf{1 1}$ & $\mathbf{4}$ & \\
\hline
\end{tabular}

Tablo 12'de incelenen ihtilaflı konulardan “Su Sıkıntısının” SBDK'ya sınıf düzeyinde yansıyan dağılımına bakıldığında en fazla 6. sınıf SBDK'na 11 yerde yansıdığı görülmüştür. En az ise 7. sınıf SBDK'na 4 yerde yansımıştır. Öğrenme alanı/Ünite olarak bakıldığında 6. sınıf düzeyinde en fazla Üretim, Dağıtım ve Tüketim başlığında yer verilmiştir. Öğrenme Alanı/Ünite bazında yansımadığı başlıklar ise sınıf düzeyleri toplamında Birey ve Toplum, Bilim, Teknoloji ve Toplum öğrenme alanlarıdır. Yansıyan kavramlar 23 yerde dolaylı 1 yerde doğrudan içerikte geçmiştir. 
Tablo 13. İhtilaflı Konu Başlığı GDO’nun Sınıf Düzeylerine Göre Dağılımının Karşılaştırması

\begin{tabular}{lcccc}
\hline \multicolumn{1}{c}{ Öğrenme Alanı } & $\begin{array}{c}\text { 5. Sinıf Ders } \\
\text { Kitabı }\end{array}$ & $\begin{array}{c}\text { 6. Sinıf Ders } \\
\text { Kitabı }\end{array}$ & $\begin{array}{c}\text { 7. Sinıf Ders } \\
\text { Kitabı }\end{array}$ & İhtilaflı Konu \\
\hline Birey ve Toplum & - & - & - & GDO \\
Kültür ve Miras & - & - & - & GDO \\
İnsanlar, Yerler ve Çevreler & - & - & - & GDO \\
Bilim, Teknoloji ve Toplum & - & - & - & GDO \\
Üretim, Dağıtım ve Tüketim & $1(\mathrm{D})$ & - & $1(\mathrm{D})$ & GDO \\
Etkin Vatandaşlık & - & - & - & GDO \\
Küresel Bağlantıllar & - & - & $2(\mathrm{D})$ & GDO \\
\hline Toplam & $\mathbf{1}$ & $\mathbf{0}$ & $\mathbf{3}$ & \\
\hline
\end{tabular}

Tablo 13'de incelenen ihtilaflı konulardan "GDO'nun” SBDK'ya sınıf düzeyinde yansiyan dağılımına bakıldığında en fazla 7. sınıf SBDK'na 3 yerde yansıdığı görülmüştür. 6. sınıf SBDK'na hiçbir yerde yansımadığı görülmüştür. Öğrenme Alanı/Ünite olarak bakıldığında 7. sınıf düzeyinde en fazla Küresel Bağlantılar başlığında yer verilmiştir. Öğrenme Alanı/Ünite bazında yansımadığı başlıklar ise sınıf düzeyleri toplamında Birey ve Toplum, Kültür ve Miras, İnsanlar, Yerler ve Çevreler, Bilim, Teknoloji ve Toplum, Etkin Vatandaşlık öğrenme alanlarıdır. Yansıyan kavramlar 4 yerde dolaylı olarak içerikte geçmiştir.

Ders kitaplarında incelenen ihtilaflı konu başlıklarının içerikte geçtiği tüm yerler analiz edilerek araştırma bulgularına yer verilmiştir. Yapılan analiz sonucu incelenen başlıkların geçtiği yerler içerikte bulunsa da az yerde ihtilaflı öğreti olarak ele alınabileceği görülmüştür. $\mathrm{Bu}$ yerlerden 5. sınıf sosyal bilgiler ders kitabında "Bilim, Teknoloji ve Toplum" öğrenme alanında "Bilim İnsanlarının Ortak Özellikleri”" başlığı altında geçen "Bilim insanları bilimsel yöntemler kullanarak araştırmalar yapar, araştırma sonuçlarını başka insanlarla paylaşır.günlük hayatımızı kolaylaştıran buluşların yapılmasında bilimsel çalışmalarda elde edilen bilgiler önemli yer tutmaktadır (Şahin, 2018, s.106-107)" "Araştırma ve inceleme yaparken konulara bilimsel yaklaşmaya özen göstermeliyiz. (Şahin, 2018, s.109)” kısmında öğretici bilim başlığını ihtilaflı öğreti olarak; "İnsanlar, Yerler ve Çevreler” öğrenme alanında "Nüfus ve Yerleşme" başlığı altında geçen "Su, yaşamımızı devam ettirebilmemiz için gerekli bir kaynaktır. Su olmadan yaşamın devam etmesi mümkün değildir. Bu nedenle geçmiş zamanlardan günümüze su kaynaklarının çevresi insanlar tarafindan yerleşim alanı olarak tercih edilmiştir. Su kaynaklarının yeterli olduğu yerlerde tarım ürünleri daha kolay yetiştirilir. Bu durum su kaynaklarının çevresinde tarıma bağll olarak nüfusun artmasını sağlar (Şahin, 2018, s.76-77)" aynı öğrenme alanında "Afetler ve Çevre Sorunları" başlığında geçen "Su kaynaklarının çeşitli etkenlerle kirlenmesine su kirliliği denir. Su kirliliğinin olduğu yerlerde insanlar içme suyuna ulaşmakta zorluk yaşar, su kaynaklarında balık ölümleri görülür. Sanayi tesislerinin atıkları, su kaynaklarına karışan kanalizasyon atıkları, konutlarda ve sanayide oluşan atık yağlar su kirliliğinin sebeplerinden bazllarıdır (Şahin, 2018, s.84)" kısmında öğretici su sıkıntısı başlığını ihtilaflı öğreti olarak; "İnsanlar, Yerler ve Çevreler” öğrenme alanında geçen “. Küresel ısınma, su kaynaklarındaki buharlaşma hızını artırır. Bu durum, canlıların içme ve kullanma suyuna ulaşmalarını önler. Dünya'mızın ortalama sıcaklığının artmasıyla birlikte buzullar erimeye başlar. Bu da buzullarda yaşayan canlıların yaşamını tehdit eder ve klylya yakın yerleşim birimlerinin sular altında kalmasına yol açabilir (Şahin, 2018, s.85)" kısmında öğretici iklim değişikliği başlığını ihtilaflı öğreti olarak işleyebilir. GDO, yok olan türler, biyoyakıt başlıkları için doğrudan içerikte gösterilecek bir yer bulunamamıştır. 6. sınıf sosyal bilgiler ders kitabında "Bilim, Teknoloji ve Toplum" öğrenme alanında "Sosyal Bilimler ve Toplum" başlığında 
geçen "Bilimsel çalışmalarla ilgili duyduğunuz en son gelişme nedir? Tartışınız. (Gültekin, Akpınar, Nohutcu, Özerdoğan \& Aygün, 2018, s.126)", "Bilimsel ve teknolojik gelişmeler gelecekteki hayatımızı nasıl etkileyecektir? Tartışınız./ "Okulunuzda bir bilim fuarı düzenlenseydi hangi konuda proje hazırlardınız? Neden? Tartışınız? (Gültekin, Akpınar, Nohutcu, Özerdoğan \& Aygün, 2018, s.128)", aynı öğrenme alanının "Haylimdeki Gerçek" başlığında geçen "Bilim insanı olsaydınız günlük hayatımızı kolaylaştıracak hangi buluşu yapmak isterdiniz? Tartışınız. (Gültekin, Akpınar, Nohutcu, Özerdoğan \& Aygün, 2018, s.134)" kısmında öğretici bilim başlığını ihtilaflı öğreti olarak; "İnsanlar, Yerler ve Çevreler başlığında geçen "Türkiye de dağlar kuzeyden güneye doğru uzansaydı yaşadığınız yerin ikliminde nasıl değişiklikler olurdu? (Gültekin, Akpınar, Nohutcu, Özerdoğan \& Aygün, 2018, s.102)" kısmında öğretici iklim değişikliği başlığını ihtilaflı öğreti olarak; "Üretim, Dağıtım ve Tüketim” öğrenme alanında geçen “Bu kaynakların bilinçsizce tüketilmesi, aşırı avlanma, ormanların tahrip edilmesi, aşırı otlatma, sanayi tesislerinin denetlenmemesi ve plansız kentleşme gibi etmenler doğal kaynakların yok olmasına sebep olmaktadır. Doğal kaynakların bilinçsizce tüketilmesi kuraklık, hava kirliliği, su kirliliği, erozyon, heyelan, gıda yetersizliği ve küresel ısınma gibi sorunlara sebep olmaktadır (Gültekin, Akpınar, Nohutcu, Özerdoğan \& Aygün, 2018, s.168)" kısmında yok olan türler başlığını ihtilaflı öğreti olarak; "Üretim Dağıtım ve Tüketim” öğrenme alanında geçen "Doğal kaynakların bilinçsizce tüketilmesi kuraklık, hava kirliliği, su kirliliği, erozyon, heyelan, gıda yetersizliği ve küresel ısınma gibi sorunlara sebep olmaktadır (Gültekin, Akpınar, Nohutcu, Özerdoğan \& Aygün, 2018, s.169)" kısmında su sıkıntısı ve iklim değişikliği başlığını ihtilaflı öğreti olarak; "Üretim, Dağıtım ve Tüketim" öğrenme alanında geçen "Enerji kaynaklarının bir kısmının ise doğada varlı̆̆ asla sona ermez. Bu kaynaklara yenilenebilir enerji kaynakları denilmektedir. Güneş, rüzgâr, su, dalga enerjisi, biyoenerji ve jeotermal enerji yenilenebilir enerji kaynaklarıdır (Gültekin, Akpınar, Nohutcu, Özerdoğan \& Aygün, 2018, s.166)" kısmında biyoyakıt başlığını ihtilaflı öğreti olarak işleyebilir. Bu incelemeler sonucunda araştırma kapsamında ele alınan konu başlıklarının içeriğe 6. sınıf düzeyinde daha etkin yansıdığı söylenebilir.

7. sınıf sosyal bilgiler ders kitabında ise "Kültür ve Miras" öğrenme alanında geçen “Avrupa'da bilimsel düşünceye verilen önem arttı. Avrupa'da birçok bilimsel çalışmanın yapıldığı Aydınlanma Çağı'na ortam hazırladı. / Coğrafi keşifler ve Rönesans'la ortaya çıkan bilimsel gerçekler sayesinde Avrupalılar kilisenin öğrettiklerini sorgulamaya başladı / Kilise'nin kontrolü ve baskısının sonucu ortaya çıkan skolastik düşünce yerini araştırmacı ve sorgulayıcı bilim anlayışı olan pozitif düşünceye bıraktı. (Yılmaz, Bayraktar, Özden, Akpınar \& Evin, 2018, s.68-69)", "Bilim, Teknoloji ve Toplum" öğrenme alanında geçen "Pozitif düşünce insanların serbestçe düşünmesine ve bilimsel çalışmalar yapmasına imkân tanımıştır. / Skolastik düşünce özgür düşünceyi yasaklayarak bilimsel gelişmelerin önünü kapatmıştır (Yılmaz, Bayraktar, Özden, Akpınar \& Evin, 2018, s.150)" kısmında bilim başlı̆̆ını ihtilaflı öğreti olarak; "Küresel Bağlantılar" öğrenme alanında geçen "Fosil yakıtların kullanılmaya başlanması, arazi kullanımının değişmesi, ormansızlaşma ve sanayi süreçleri sonucunda ortaya çıkmıştır (Yılmaz, Bayraktar, Özden, Akpınar \& Evin, 2018, s.232)" kısmında biyoyakıt başlığını ihtilaflı öğreti olarak; "Küresel Bağlantılar" öğrenme alanında geçen "Atmosferde biriken sera gazlarl, atmosferin kimyasal özelliklerini etkilemektedir. Uzun vadede ise sera etkisi nedeniyle küresel ısınmaya ve sonuç olarak iklim değişikliğine neden olmaktadır (Yılmaz, Bayraktar, Özden, Akpınar \& Evin, 2018, s.232)" "Sinıfta arkadaşlarınızla gruplar oluşturunuz. Aşağıda verilen küresel sorunlardan birini seçerek bu küresel sorunun çözümüne yönelik geliştirdiğiniz çözüm önerilerinizi aşă̆ıya yazınız.-Küresel iklim değişimi, doğal afetler, açlık, terör, göç-(Yılmaz, Bayraktar, Özden, Akpınar \& Evin, 
2018, s.236)" kısmında iklim değişikliği başlığını ihtilaflı öğreti olarak; "Küresel Bağlantılar" öğrenme alanında geçen "Kurak ve yarı kurak alanlarındaki su kaynakları özellikle kentlerdeki su kaynaklarının durumu, sorunlara yenilerini ekleyecek ve içme amaçlı su ihtiyacı daha da artacaktır. Kuraklığa neden olan şartların devam etmesi hâlinde, gelecek yıllarda suyla ilgili daha büyük sikıntılar meydana gelebilecektir. Türkiye'nin özellikle çölleşme tehlikesi bulunan kesimlerinin tarım, ormancılık ve su kaynakları açısından olumsuz etkilenecektir (Y1lmaz, Bayraktar, Özden, Akpınar \& Evin, 2018, s.235)" kismında iklim değişikliği başlığı ihtilaflı öğreti olarak işlenebilir. Biyoyakıt konusunda 7. sınıf düzeyinde etkin şekilde ele alınacak içerik görülmemiştir.

\section{TARTIŞMA VE SONUÇ}

Araştırma kapsamında 2018/2019 eğitim öğretim yılında incelenen 5. 6. ve 7. sınıf SBDK'larına bakıldığında, 5. sınıfta özel bir yayınevinin MEB adına yazdığı bir kitaptan, 6 . ve 7. sınıflardaysa MEB'in bünyesinde hazırlanan birer kitaptan oluştuğu görülmüştür. Kitaplarda yenilenen 2018 öğretim programlarındaki değişikliklerin yansıtıldığı görülebilir. Ayrıca eski kitaplarda her ögrenme alanına ait çeşitli ünite başlıkları verilirken yeni kitaplarda öğrenme alanlarının her birinin ünite başlığı olarak yer verildiği görülmüştür.

Alanyazına bakıldığında sosyal bilgiler ve çeşitli alanlarda ilgili ihtilaflı konular da çalışmaların olduğu görülebilir. Yazıcı ve Seçgin (2010) yaptığı araştırmada ihtilaflı konuların derslerde işlenmesi açısından öğretmenlerin olumlu yönde görüş bildirdiklerini belirtmiş, ayrıca öğretmenlerin ihtilaflı konuların öğretiminin düşünme becerileri ve vatandaşlık yeterliliklerinin aktarımında verimli olacağını belirttiğini vurgulamıştır. Bu nedenle ihtilaflı konuların içerikte yer verilmesi ne kadar önemliyse öğretim sürecinde öğretici tarafindan etkin şekilde işlenmesi de bir o kadar önemli olduğu söylenebilir. Çopur (2015) de konuyla ilgili yaptığı araştırmasında, ihtilaflı konuların öğretiminin birçok beceri ve davranışın öğrenciye kazandırılmasında yardımcı olabileceğini belirtmiştir. İhtilaflı konular, iletişim, sorgulama, problem çözme, eleştirel düşünme, farklılıklara saygı gibi üst düzey becerilerin öğrencilere kazandırılmasını kolaylaştırabilir. İhtilaflı konuların öğretimi, öğrencinin etkin vatandaşlığına katkı sunabilir. Uyuşmazlıklara ve sorunlara çözüm getiren uzlaşmacı bireysel ve toplumsal gelişimi sağlar. İhtilaflı konuların öğretim sürecinde etkisinin bu kadar önemli olduğunu belirten araştırmalara rağmen içeriğe yansitılmasında eksikliklerin olduğu söylenebilir. Tatar (2018) bu konuda, Türkiye'de ihtilaflı konuların belirlenme sürecinin yapıldığı ancak bu konuların ilk ve ortaokul derslerine aktarımında sorunların olduğunu belirtmiştir. Tatar (2018) araştırmasında, ilk ve ortaokul derslerinin öğretim programlarında amaç, içerik ve öğrenme-öğretme süreçleri gibi programın temel yapısını oluşturan başlıklarda ihtilaflı konuların ihmal edildiği sonucuna ulaşmıştır. Öğrencilere erken dönem eğitimlerinde ihtilaflı konuların etkin bir şekilde verileceği en fazla içerik sosyal bilgiler derslerinde görülebilir. İhtilaflı konular, sosyal bilgiler derslerine ve programlarına ekonomik, siyasi, toplumsal, kültürel, güncel alanlardan seçilerek, öğrencinin yakın çevresinden başalanıp yerel, ulusal hatta uluslararası ölçekte içeriklerle aktarılmaya çalışılabilir. Konu seçiminin belli ilkeler çerçevesinde olması etkili öğrenme ve öğretim için faydalı olacaktır (Çopur, 2015, s.11). İhtilaflı konuların sosyal bilgiler derslerinde öğretimi öğrencilerin, aktif katılımı sağlayan, demokrasiyi bireysel ve toplumsal anlamda kabullenen, ulusal ve uluslararası sorunlara duyarlı olan, problemlere uzlaşmacı çözümler getiren, farklılıklara saygı duyan, eleştirel düşünme becerileri gelişmiş etkin vatandaşlık yapabilen birey olmasını sağlayabilir (Çopur, 2015, s.16). Akman ve Bastık (2016) ise yaptıkları çalışmada sosyal bilgiler ders kitaplarında ihtlaflı konu başlıklarından aile kavramını incelemiş olup aile 
kavramının içerikte yer aldığını ancak kitaplarda verilen yoğun içerik nedeniyle tartışma yapılmasının güçleştiğini belirtmiştir. $\mathrm{Bu}$ durumun ders kitaplarında aktarılmaması tartışılması gereken birçok konunun tartışılmasından uzaklaşılmasına, tartışmalı konuların görmezden gelinmesine neden olabileciğini çalışmalarında belirtmiştir (Akman \& Bastık, 2016). Avaroğulları (2015) bu konuda ihtilaflı konuların daha iyi bir öğrenme ortamına aktarılması için sosyal bilgiler öğretmenlerinin hizmet içi eğitimle ihtilaflı konular hakkında bilgilendirilmesinin önemine değinmiştir. $\mathrm{Bu}$ nedenle ortaya çıkan durumun, ihtilaflı konuların özellikle demokratik bir vatandaş eğitimi ve demokratik bir toplum oluşturmayı amaçları arasında tutan sosyal bilgiler eğitimi derslerinde (Safran, 2012), daha nitelikli içeriklerle ve öğretim durumlarıyla ders kitaplarına yansıtılması gerekliliğini ortaya koyduğu söylenebilir. Bireyin belirli konularda fikirlerini beyan etmelerini engellemek veya düşünce özgürlüğünü baskılayacak demokratik ve çağdaş bir yaşam öğretisine uymayan her şey, birey ve toplum tarafından düşüncesine kendisine sınırlama getirdiği şeklinde anlaşılarak çoğunlukla karşı tepki görebilir (Y1lmaz, 2012). Bu gibi durumları engellemek ve demokratik bir tartışma kültürünü toplumsal düzen içerisinde kazandırmak için ihtilaflı konuların sosyal bilgiler derslerinde ve ders kitapların etkin bir şekilde verilmesinin önemli olduğu söylenebilir.

Araştırma kapsamında belirlenen problemler çerçevesinde elde edilen bulgulara yönelik ortaya çıkan sonuçlarda ihtilaflı konu başlıklarından Bilim, incelenen 5. sınıf sosyal bilgiler ders kitabı içeriğinde en fazla Bilim, Teknoloji ve Toplum öğrenme alanına yansımıştır. İhtilaflı konu başlığı derse hazırlık aşamasındaki sorularda, bilim insanlarının ve bilimsel etiğin anlatıldığı konu başlıklarında içeriğe yansıdığı görülebilir. Diğer öğrenme alanlarına bakıldığında kısmi olarak her bir öğrenme alanında bilim kavramına yer verildiği ve konu başlıklarına yansıtıldığı söylenebilir. Bilim kavramından sonra en fazla su sıkıntısı konu başlığı içeriğe yansıtılmıştır. Az düzeyde de olsa iklim değişikliği, GDO, yok olan türler kavramlarınında içeriğe yansıdığı söylenebilir. Ancak 5. sınıfta biyoyakıt konusuna değinilmediği söylenebilir.

Araştırma kapsamında belirlenen problemler çerçevesinde elde edilen bulgulara yönelik ortaya çıkan sonuçlarda ihtilaflı konu başlıklarından Bilim, incelenen 6. sınıf sosyal bilgiler ders kitabı içeriğinde en fazla Bilim, Teknoloji ve Toplum öğrenme alanına yansımıştır. İhtilaflı konu başlığı derse hazırlık aşamasındaki sorularda, sosyal bilimler ve toplum konusunda ve hayalimdeki gerçek konu başlıklarında içeriğe yansıdığı görülebilir. Diğer öğrenme alanlarına bakıldığında kısmi olarak her bir öğrenme alanında bilim kavramına yer verildiği ve konu başlıklarına yansıtıldığı söylenebilir. Bilim kavramından sonra en fazla su sıkıntısı konu başlığı içeriğe yansıtılmıştır. Az düzeyde de olsa iklim değişikliği, biyoyakıt, yok olan türler kavramlarınında içeriğe yansıdığı söylenebilir. Ancak 6. sınıfta GDO konusuna değinilmediği söylenebilir.

Araştırma kapsamında belirlenen problemler çerçevesinde elde edilen bulgulara yönelik ortaya çıkan sonuçlarda ihtilaflı konu başlıklarından Bilim, incelenen 7. sınıf sosyal bilgiler ders kitabı içeriğinde en fazla Bilim, Teknoloji ve Toplum ile Kültür ve Miras öğrenme alanlarına yansımıştır. İhtilaflı konu başlığı Bilim, Teknoloji ve Toplum öğrenme alanında derse hazırlık aşamasındaki sorularda, bilimsel gelişmelerin 1şığında konu başlı̆̆ı ve özgür düşüncenin öneminin anlatıldığı konu başlıklarında; Kültür ve Miras öğrenme alanında ise Avrupa'da uyanış başlığında Avrupa'da Ortaçağ ve sonrası dönemdeki konularla ilişkili başlıklarda içeriğe yansıdığı görülebilir. Diğer öğrenme alanlarına bakıldığında İnsanlar, Yerler ve Çevreler hariç kısmi olarak her bir öğrenme alanında bilim kavramına yer verildiği 
ve konu başlıklarına yansıtıldığı söylenebilir. Bilim kavramından sonra en fazla iklim değişikliği konu başlığı içeriğe yansıtılmıştır. Az düzeyde de olsa su sıkıntısı, GDO, biyoyakıt kavramlarınında içeriğe yansıdığ 1 söylenebilir. Ancak 5. sınıfta yok olan türler konusuna değinilmediği söylenebilir.

Araştırma sonuçlarına göre incelenen 5. 6. ve 7. sınıf sosyal bilgiler ders kitaplarında içeriğe yansıtılan ihtilaflı konu başlığı bilimin içerikte doğrudan kavram olarak yansıtıldığı söylenebilir ancak diğer başlıkların çoğu yerde dolaylı ifadelerle yansıtıldığı görülmüştür.

Araştırma sonuçlarına göre 5. sınıfta en fazla f(54) bilim konu başlı̆̆ 1 sıklıkla içeriğe yansımış, biyoyakıt konu başlığ 1 ise $f(0)$ içeriğe yansıtılmamıştır. 6. sınıfta en fazla $f(127)$ bilim konu başlığı sıklıkla içeriğe yansımış, GDO konu başlı̆̆ yansıtılmamıştır. 7. sınıfta en fazla $\mathrm{f}(119)$ bilim konu başlığı sıklıkla içeriğe yansımış, yok olan türler konu başlı̆̆ 1 ise $\mathrm{f}(0)$ içeriğe yansımamıştır.

Araştırma sonuçlarına göre 5. 6. ve 7. sınıf sosyal bilgiler ders kitapları genelinde bilim konu başlığı en fazla Bilim, Teknoloji ve Toplum öğrenme alanı içeriğinde, yok olan türler konu başlığı en fazla Üretim, Tüketim ve Dağıtım öğrenme alanı içeriğinde, biyoyakıt konu başlı̆̆ en fazla Üretim, Tüketim ve Dağıtım öğrenme alanı içeriğinde, iklim değişikliği konu başlığ en fazla Küresel Bağlantılar öğrenme alanı içeriğinde, su sıkıntısı konu başlığı en fazla Üretim, Tüketim ve Dağıtım öğrenme alanı içeriğinde, GDO konu başlığı en fazla Küresel Bağlantılar öğrenme alanı içeriğinde yansıdığı söylenebilir. 5. 6. ve 7. sınıf düzeyinde sosyal bilgiler ders kitaplarında ihtilaflı konu başlıklarından bilim en fazla 6. sınıfta, en az ise 5 . sınıfta içeriğe yansımıştır. İhtilaflı konu başlıklarından yok olan türler 5. ve 6. sınıfta eşit düzeyde yansımış, 7. sınıfta ise yansımadığ s söylenebilir. İhtilaflı konu başlıklarından biyoyakıt 6 . ve 7. sınıfta eşit düzeyde, 5. sınıfta ise yansımadığı söylenebilir. İhtilaflı konu başlıklarından iklim değişikliği en fazla 7. sınıfta, en az ise 5. sınıfta içeriğe yansımıştır. İhtilaflı konu başliklarından su sıkıntısı en fazla 6. sınıfta, en az ise 7. sınıfta içeriğe yansımıştır. İhtilaflı konu başlıklarından GDO en fazla 7. sınıfta, 6. sınıfta ise yansımadığ söylenebilir.

Araştırmanın sonuçları kapsamında 5. 6. ve 7. sınıf düzeyinde 2018/2019 yılında okutulan SBDK'ların içeriğinde yer alan ihtilaflı konular içerisinden Bilim" ve alt başlıkları "Yok Olan Türler, Biyoyakıt, İklim Değişikliği, Su Sıkıntısı, Genetiği Değiştirilmiş Organizmaların” ele alındığı bu çalışmada konu ile ilgili ders kitaplarındaki bulgulara göre ilköğretim öğrencilerinin gelişim ve öğrenme seviyelerinin genel olarak gözetildiği söylenebilir. İçerikte, incelenen ihtilaflı konu başlıklarının bazılarına çeşitli görseller, sorular, okuma metinleri farklı yazı türleri ve yönlendirmelerle etkin şekilde yer verilmeye çalışılmıştır. Ancak içeriğin yoğunluğu, kazanımların öğretim sürecinin temelinde yer alması, öğrencilerin sınav odaklı çalışmaya yönelimi, zaman yönetimi gibi nedenler ders sürecinde yeterince ve etkili tartışmalı konu öğretimini etkileyebilir. İncelenen ihtilaflı konu başlıklarından içeriğe en fazla "bilim" kavramı ve konularının yansıdığı görülmüştür. "Yok olan türler, Biyoyakıt, GDO" kavramları ve konularının ise içeriğe yeteri kadar yansıtılmadığı söylenebilir. Tüm sınıf düzeylerinin toplamında bilim kavramı 300 yerde, yok olan türler kavramı 4 yerde, biyoyakıt 4 yerde, iklim değişikliği 11 yerde, su sıkıntısı 24 yerde, GDO 4 yerde geçmiştir. İncelenen ihtilaflı konuların her bir başlığının içeriklerine bakıldığında 21. yüzyıl toplumunu yakından ilgilendiren kavramlar olduğu söylenebilir. Günümüz toplumu hızlı gelişen ve değişim süreci yaşayan bir yapıda ilerlemekte, teknolojik, sosyolojik, bilimsel, ekonomik gibi birçok temelde yerel ve küresel kalkınma yaşamaktadır. Köroğlu ve Köroğlu, (2016) bilimin insanlık 
açısından eskiden günümüze kadar varoluşunda büyük katkılarının olduğunu, günümüzde ise daha fazla modernite kazanarak insanlığın ayrılmaz parçası haline geldiğini belirtmiştir. Kısaca bilim ve bilimselliği insanın hakikate ulaşma çabalarından birisi olarak göstermiştir. İnsanlık için önemli bir yeri olan bilim ve bilim çerçevesinde ele alınacak konular öğrencilerin erken dönemde bilişsel dünyasına kazandırılması açısından sosyal bilgilere 5. 6 . ve 7. sınıf ders kitaplarında yeterince yer verildiği görülmüştür. Sosyal bilgiler ders kitaplarında ihtilaflı konular içeriğe başarılı ve etkin şekilde yansıtılsada yeterli olmayabilir. Hizmet öncesi eğitim kapsamında sosyal bilgiler öğreticilerinin yetiştirilmesini sağlayan sosyal bilgiler eğitimi lisans programlarında tartışma kültürü, etkin öğretim, öğrenme sürecini yönlendirme gibi konularda da öğretici sınıfın iyi yetiştirilmesi gerekebilir (Kirkit, 2019).

İçeriklerde bilim kavramına rahatlıkla yer verilmesinin önemli nedenlerinden birisi de Köroğlu ve Köroğlu'na (2016) göre bilim kavramının kapsayıcı olmasına, çok fazla kullanılmasına, en çok itibar edilen ve modern yaşam da referans kaynağı olarak alınan kavramlardan olmasına bağlamıştır. İncelenen sosyal bilgiler kitaplarında da birçok konuyla ilişkilendirilmiş olan bilim kavramının "Bilim, Teknoloji ve Toplum" öğrenme alanı hariç, içeriğe yansıyan durumu incelendiğinde ihtilaflı konu olarak çok az yerde işlenebilecek düzeyde olduğu söylenebilir. İçerikteki bilgiler öğrenciye etkin tartışma kültürü sunacak düzeyde olmadığı söylenebilir. Ancak öğreticinin süreci yönlendirmesiyle etkin bir şekilde ihtilaflı öğreti olarak ders işlenebilir. Diğer başlıklarda da yine bu vurgu yapılabilir. Ayrıca diğer başlıklarda içerikte yer verilmeyen kavramlar olduğu gibi çoğu kavram dolaylı olarak yer almıştır. İnsan yaşamı için sürdürülebilir kalkınma düzeyinin sağlanması, ulusal ve uluslararası alanlarda strateji planları ve sözleşmeler yapılarak gerçekleştirilmektedir. $\mathrm{Bu}$ durumun ise türlerin varoluşu, ekosistemin korunması, biyolojik çeşitliliği koruma gibi doğayı ve insanı koruyan bütünün (Demirayak, 2002) "yok olan türler, GDO, iklim değişikliği, su sıkıntısı" gibi başlıklarla ihtilaflı olarak öğretilmesini önemli kıldığı söylenebilir. Öğrenci ihtilaflı öğretilerle öğreneceği bu konularda farkındalık kazanabilir. Öğrencinin bu gibi ihtilaflı konulardaki farkındalığı toplumsal yaşamı ve sürdürülebilir düzeni de ileri dönemde etkilediği söylenebilir. Nitekim eğitim sürecinde demokratik öğretileri ve tartışma kültürünü kavrayan bir toplum, şehir yaşamının getirdiği sorunları çözebilen, toplumsal huzuru sağlayabilecek bir tartışma ortamı sağlayan kazanımları öğrenmiştir (Hassan \& Lee, 2018). Bu nedenle 5. 6. ve 7. sınıf sosyal bilgiler ders kitaplarında içeriğe az seviye de yansitılan "yok olan türler, GDO, iklim değişikliği, su sıkıntısı" gibi konu başlıklarının ders kitaplarının tekrar düzenlenmesi aşamasında ihtilaflı konular bağlamında ele alınması ders süreci açısından verimli olabilir.

İncelenen ihtilaflı konu başlıklarının aslında tartışma ve uzlaşı anlamında ele alınışlarıda önemli bir öğreti konusu olabilir. İhtilaf içeren konular, öğrenciye öğretim aşamasında sağlayacağı kazanımlar, birey ve toplum hayatına sağlayacağı faydalar açısından da değerlendirilebilir. Günümüzde özellikle bilim kavramı konusunda güncel tartışmalar görülebilir. Bilimi tek doğru kabul eden bir bireyin değer yargıları kapsamında ele alınacak bazı konularda duyarlılı̆̆ az olabilir. Yine günümüzde medya ve toplumda karşımıza çıkabilen Din mi? Bilim mi? Benzeri soruların süreklilik arz eden tartışmalara neden olduğu söylenebilir. Sosyal bilgiler dersinde Bilim,Teknoloji ve Toplum öğrenme alanı başlığında özellikle ele alınabilecek bu konu, öğrencinin Reform, Rönesans ve Aydınlanma Çağı gibi tarihsel dönemlerde yaşananları ihtilaflı konular bağlamında öğrenmesini daha verimli kılabilir.Yine bir örnek olarak verecek olursak, Dünya tarihinde önemli tartışmalara neden olan Dünya'nın dönüşü konusu Orta Çağ işlenirken tartışma kültürü ile bilim konusu ilişkilendirilerek verilebilir. Bir örnekle açıklayacak olursak; Güneş mi Dünya'nın etrafında 
dönüyor yoksa Dünya mı Güneş’in etrafinda dönüyor? sorusu Kopernik-Aristarkos ikileminde bir münazara açarak başlanıp, Kopernik'in dönemi içerisinde Dünya'nın dönüşünü kanıtlarken yaşadıklarını öğrenciye aktırılıp düşüncenin önemini kavramasının sağlanması, öğrencinin tartışma kültürünü de geliştirilebilir. Yine güncelliğini her zaman koruyabilen bir konu olan evrim konusunda Evrim var mıdır? sorusunun din-bilim tartışmasının etkin işlenmesine katkısı olabilir. Ancak ülkelerin önemsediği küresel etki yaratan faaliyetleri, yok olan türler konusunda olumsuz etkiler oluştursa da bunları bırakmaması önemli tartışma konularından olabilir. Özellikle ABD, ÇHC, Rusya Federasyonu, Almanya gibi sosyoekonomisi, teknolojisi, yaptırım ve üretim gücü büyük ülkelerin faaliyetleri sonucu etkilenen dünya, incelenen ihtilaflı konu başlıklarında yer alan iklim değişikliği, su sıkıntısı, küresel ısınma gibi konularda tartışma yaratacak konuları ortaya çıkarabilir. Bu ülkeler birçok önleyici protokol, anlaşma ve uzlaşıdan uzak kalarak faaliyetlerini sürdürmektedir. Tartışma ve uzlaşı kavramları bu noktada güç kavramına yenilmiştir. Günümüzü ilgilendiren diğer önemli konu olan GDO, bireyin yaşamında öenmli tartışma yaratabilecek konulardandır. Üretim-tüketim ikileminde besinlerin ve canlı yaşamını direk etkileyen diğer konuların GDO ile ilişkisi tartışmalı birçok konuyu ortaya çıkarabilir. Örnek olarak verecek olursak, besinlerin daha ucuza mal edilerek üretimine olanak sağlayan GDO bir besinin insan sağlığına etkisi olumsuz olabilir. Fakat küresel sistem bu konuyu daha çok ekonomik, karşılanabilir mal, sürdürülebilir toplum hayatı gibi konulara odaklanarak değerlendirebilir. Ancak GDO’lu bir besin doğal besinlere göre insan sağlığını olumsuz etkileyebilir. Bu konu sağlık eğitimi konusunda önemli bir tartışmalı öğreti olabilir. Bu nedenle araştırma sonucunda sosyal bilgiler ders kitaplarında bilim kavramına yeterince yer verildiği görülsede diğer önemli başlıkların da içerikte daha fazla yer verilmesi gelecek toplumu açısından önemli sonuçlar ortaya çıkarabilir.

İhtilaflı konuların öğretiminde önemli noktalardan birisi de ders kitapları ve öğretim programlarının konuyla ilgili içeriklerinin bilimsel düzeyde yeterli seviyede olması gerekliliği olabilir. Ayrıca hizmet öncesi eğitim alan öğretmenlere, eğitim lisans programlarında da ihtilaflı konuların öğretimine yönelik içerikler sunulabilir. MEB (2018) bünyesinde bulunan kurumlardan TTKB'nın ele aldığı yenilenen sosyal bilgiler öğretim programında ihtilaflı konulara "Sosyal Bilgiler Dersi Öğretim Programı'nın Uygulanmasında Dikkat Edilecek Hususlar" başlığında yer alan "9. Kazanımlarla ilgili güncel ve ihtilaflı konular, farklı tartışma teknikleri kullanılarak problem çözme, eleştirel düşünme, kanıt kullanma, karar verme ve araştırma becerileriyle ilişkilendirilerek sınıfa taşınabilir." maddesinde değinmiştir. Ders kitaplarındaki içerikleri oluşturan hazırlayıcıların ise içeriğe aktarılan ihtilaflı konu başlıklarını ihtilaflı öğreti amacıyla az seviyede yer verdiği söylenebilir. Ders kitaplarında ihtilaflı konu başlığı olarak en fazla geçen "Bilim" başlığında bile ihtilaflı öğreti olarak işlenecek içerik az sayıdadır. Bu durumu ise süreci yöneten öğretmenler esnek bir yaklaşımla aşabilir. Ayrıca bilgiye ulaşmanın kolaylaştığı günümüzde, bilişim, teknoloji ve araştırma temelli yaklaşımlarda kullanılarak öğrenciye daha verimli ihtilaflı öğretiler kazandırılabilir (Kaya, 2012; Öztürk; 2017; MEB,2018).

İhtilaflı konuların öğretiminde bir diğer önemli konunun da katılım sağlama olduğu söylenebilir. İhtilaflı konuların nitelikli ve etkin bir tartışma kültürü içerisinde işlenmesi için öğrencilerin katılım düzeylerinin önemli olduğu söylenebilir. MEB (2018) sosyal bilgiler öğretim programının özel amaçlarında yer alan madde 14'te "Katılımın önemine inanmaları, kişisel ve toplumsal sorunların çözümü için görüşler belirtmeleri," açıklamasında katılımın toplumsal düzeydeki önemine de değinilmiştir. Ayrıca programda sosyal bilgiler dersinin katılma ve katılım sağlamayı bireye kazandıran bir ders olduğu da birçok yerde 
vurgulanmıştır. Katılım sağlamak bir tartışmalı konunun çözümünde ön koşullardan biri olabilir. Bir ders sürecinde öğrenci düşüncesini katılım sağlayarak söyleyebilir, düşüncelerini diğer arkadaşlarıyla paylaşabilir. Öztürk (2017) ve Tuncer (2018) ihtilaflı konuların öğretiminde ve katılım konusunda; öğretmenin ihtilaflı konuların öğretiminde öğrenci katılımını sağlaması gerektiğini, ihtilaflı konuları ders sürecinde işlemeden önce kendisinin konularla ilgili gerekli bilgiye sahip olmasının gerekliliğini, dersten önce planlı ve programlı bir şekilde gelmesinin önemli bir etken olduğunun, öğrencilerin yeterince ilgisini tartışmalı konuya çekerek ders esnasında öğrencilerin tartışmalarını iyi bir şekilde yönetip yönlendirmesinin gerektiğini belirtmiştir. Ayrıca öğretmenler bu süreci yönetirken ihtilaflı konuların öğretiminde kullanacağı yaklaşımı da iyi seçmelidir. Rossi (1996) ihtilaflı konuların öğretiminde kullanılan bu yaklaşımları problem çözme, karar verme, ahlaki akıl yürütme, büyük ve küçük grup tartışmaları olarak belirtmiştir.

Araştırmanın sonuçları kapsamında bir diğer önemli konunun tartışmalı konu başlıklarının güncelliği ve toplumsal yapının etkisinde nasıl şekillendiği durumudur. Türkiye'de güncelliğini koruyan din, milli tarih, siyasi konular, toplumsal cinsiyet, sosyalleşme, adalet, istismar, eğitim, dil, çevre kirliliği, küreselleşme, demokrasi, şiddet, medya ve daha birçok konunun eğitimin birçok kademesinde yer alan içeriklere yansıdığ 1 www.eba.gov.tr adresinde yer alan MEB ders kitapları incelendiğinde görülebilir. İbret, Karasu ve Recepoğlu (2016)'nun yaptığı çalışmada toplumla ilgili tartışmalı(ihtilaflı) konuların eğitim, çevre kirliliğii, işsizlik, terör, değerlerin kazandırılmaması, demokrasi, kültürel yozlaşma, adalet, trafik, dil, din, ırk ve cinsiyet ayrımı, şiddet, medya ve basın özgürlüğü olduğunu belirtmiştir. Hess (2005) ise sosyal bilgiler derslerinde sıklıkla işlenen ihtilaflı konuların demokrasi, çevre kirliliği, insan hakları, internet, tv yayınları, şiddet, doğal afetler olduğunu belirtmiştir. Öztürk (2017) güncel ihtilaflı konular konusuna değinerek sosyal bilgiler derslerinde işlenen bu konular da öğrencilerin yeterince tartışmaya katılmadığını belirtmiştir. Öğretmenlerin çoğu kez sınıf ortamına getirdiği ih ihilaflı konuların ders sürecinde işlenirken yönetimi iyi olsa da sınıf üyelerinin tümünün aynı tepkiyi göstermeyerek derse katılmaması bu konuları daha çok açıklayıcılıkla derste verilmesine neden olduğu söylenebilir. Clabough, Philpott, McConkey ve Turner (2010) ihtilaflı konuların ders sürecinde etkin bir şekilde işlenmesi için öğretene sunulan programın bu yönde destekleyici içerikler bulundurması ve sistem-yönetici tarafından destekleyici bir yönlendirmenin olması gerektiğini belirtmiştir.

Araştırma kapsamında geniş çerçevede incelenen ve analiz edilen des kitaplarının bulgu ve yorumları yukarıdaki gibidir. Sosyal bilgiler açısından ihtilaflı konuların her birinin öğretimi, değer, beceri ve program amaçlarının gerçekleşmesinde etkili olabileeği gibi sosyal bilgiler ders kitaplarının içeriğini de daha zengin ve öğretici kılabilir. Bu konuda Öztürk (2017) ihtilaflı konuların özellikle sosyal bilgiler derslerinde yer verilmesinin öğrenciye kazandıracağı birçok özelliğin olacağını belirtmiştir, Öztürk (2017) ihtilaflı konuların sınıf içinde işlenmesinin önemli nedenlerini şu şekilde açıklamıştır:

- Öğrencileri çoğulcu demokrasideki vatandaş rolüne hazırlamak.

- Eleştirel düşünme becerisini geliştirmek.

- Kişiler arası iletişim becerilerini geliştirmektir. 


\section{ÖNERILER}

Araştırma kapsamında elde edilen bulgular, yorumlar ve sonuçlar ışığında, bu araştırmanın ihtilaflı konularla ilgili sosyal bilgiler alanında yapılacak diğer çalışmalara katkı sağlaması açısında önemli olduğu söylenilebilir. Avrupa Konseyi'nin (2019) raporunda ihtilaflı konuların öğretimine yönelik belirtilen her başlığın hem sosyal bilgiler açısından hem de diğer alanlar açısından öğrenme ve öğretme sürecinde ayrı bir önemli yerinin olduğu da söylenebilir. Sınıf düzeyleri karşılaştıııldığında "GDO, Su Sıkıntısı, Yok Olan Türler, İklim Değişikliği ve Biyoyakıt" başlıklarının geçtiği yerlerin tamamı bile içerikte bilim başlığını geçmemiştir. Oysa insan geleceğinin en önemli ve yeni konularından olan bu başlıklara özellikle sosyal bilgiler derslerinde daha fazla yer verilebilir. Ayrıca bu başlıklar Fen bilimleri dersiyle de ilişkilendirilerek disiplinlerarası öğretiler olarak sürece yansıtılabilir. Bu gibi ihtilaflı konuların ortaokullarda verilebileceği ders içerikleri daha çok sosyal bilgiler ve fen bilimlerinde görülebilir. $\mathrm{Bu}$ nedenle ihtilaflı konularla ilgili çalışmaların çeşitli alanlara disiplinlerarası ve ilişkisel olarak fayda sağlayacağı söylenebilir. Sosyal bilgiler ders kitaplarında ihtilaflı konulara yer verildiği incelemelerde görülse de sınıf düzeylerinde yeterince dengeli bir dağılımın olmadığı da görülebilir. İçeriğe yansıtılacak konuların tartışma kültürünü geliştirecek, düşündürücü, sorgulayıcı ve eleştirel bakış açısı kazandıracak içerikler olması, öğrencilerin öğrenmelerine katkı sağlayabilir.

İtilaflı konular çerçevesinde yapılan bu çalışmanın alanyazında yapılacak olan çalışmalara ve sosyal bilgiler eğitim-öğretimine katkı sağlaması düşünülmüştür.

\section{KAYNAKÇA}

Akman, Ö., \& Bastık, U. (2016). Sosyal bilgiler ders kitaplarında ihtilaflı konular içerisinde yer alan 'aile' kavramının incelenmesi: Bir içerik analizi. Trakya Üniversitesi Eğitim Fakültesi Dergisi, 6(2), 247-263.

Avaroğulları, M. (2015). Sosyal bilgiler öğretiminde tartışmalı konularla ilgili bir eylem araştırması. NWSAEducation Sciences- E-Journal of New World Sciences Academy, 10(2), 139- 150.

Avrupa Konseyi (2019. 07.19). Modül 7:İhtilaflı (tartış̧alı) konuların öğretimi. Edchreturkey. http://www.edchreturkeyeu.coe.int/Source/Resources/Trainingset/Module7_Teaching_Controversial_Is sues tr.pdf.

Aydemir, M. (2017). Examination of middle school social sciences text books in terms of skills included in the middle school social sciences course curriculum. International Journal of Contemporary Educational Studies, 3(2), 1-17.

Bayrakcı, M. (2005). Ders kitapları konusu ve ilköğretimde ücretsiz ders kitabı dağıtımı projesi. Milli $\quad$ Eğitim Dergisi, 165, 1-13.

Büyüköztürk, Ş., Çakmak, E. K., Akgün, Ö. E., Karadeniz, Ş., \& Demirel, F. (2016). Bilimsel araştırma yöntemleri (21. b.). Pegem Akademi.

Clabough, J., Phipott, S., McConkey, L. \& Turner, T. (2010). Teachers' struggles with controversial issues. facing the demon. National Social Sclence Journal, 38(2), 1-15.

Çam, İ. D., Yılar, M. B. \& Ünal, O. (2020). Son dönem Osmanlı ve güncel ders kitaplarında tasarruf değeri. Ondokuz Mayls Üniversitesi Eğitim Fakültesi Dergisi, 39(3), 350-374.

Çopur, A. (2015). Sosyal bilgiler öğretmenlerinin tartısmalı konuların öğretimine ilişkin düşüncelerinin incelenmesi. [Yayımlanmamış Yüksek Lisans Tezi, Uludağ Üniversitesi Eğitim Bilimleri Enstitüsü], YÖK Ulusal Tez Merkezi Veri Tabanı.

Demirkaya, H. G. (2008). Sosyal bilgiler ders kitaplarında güncel konular. Türkiye Sosyal Araştırmalar Dergisi, $1,117-134$. 
Ersoy, A. F. (2013). Sosyal bilgiler öğretmen adaylarının tartışmalı konulara katılımını etkileyen etmenler. Sosyal Bilgiler Eğitimi Araştırmaları Dergisi-Journal of Social Studies Education Research, 4(1), 2448.

Gültekin, G., Akpınar, M., Nohutcu, M., Özerdoğan, P., \& Aygün, S. (2018). Ortaokul ve imam hatip ortaokulu sosyal bilgiler ders kitabı 7. MEB.

Günal, H. (2018). Tarih öğretmen adaylarının tartışmalı ve hassas konuların öğretimine yönelik eğitim alma durumları. Turkish History Education Journal, 7(2), 414 - 442.

Hassan, A. M., \& Lee, H. (2018). Controversial 1ssues relevant to sustainable urbanism: a review of global urban tendencies. European Journal of Sustainable Development Research, 2(1), 1-17.

Hayırsever, F., \& Kisakürek, M. A. (2014). Evaluation of social studies textbook in terms of the aimed skills to be acquired by students according to the primary school curriculum. International Journal of Curriculum and Instructional Studies, 4(8), 23-42.

Hess, D. E. (2005). How do teachers' political views influence teaching about controversial issues. Social Education, 69(1), 47-48.

İbret, B.Ü, Karasu, E. \& Recepoğlu, S. (2016). Sosyal bilgiler öğretmen adaylarının toplumsal sorunların tespitine yönelik görüşleri. Abant İzzet Baysal Üniversitesi Ĕ̈itim Fakültesi $\quad$ Dergisi, $\quad 16(2), \quad 1295-$ 1319.

İlhan, G., Şeker, M., \& Kapıcı, H. (2015). Sosyal bilgiler beşinci sınıf ders kitaplarında turizm kavramının yeri. Uluslararası Alan Eğitimi Dergisi, 1(1), $42-62$.

İ.U.B. (2020, 12 18). Controversial issues.

https://www.indiana.edu/search/?q=controversial\%20issues/https://citl.indiana.edu/teachingresources/diversity-inclusion/managing-difficult-classroom-discussions/index.html.

İ.U. (2020, 12 20). Managing difficult classroom discussions. Center for Innovative Teaching and Learning. https://citl.indiana.edu/teaching-resources/diversity-inclusion/managing-difficult-classroomdiscussions/index.html.

Jofre, M. I., Kolstrein, A. M., Gianella, V., \& Iglesias, R. (2015). Teaching of 'controversial issues' in history and social science from teachers' perspective. Estudios Pedagogicos, 41(1), 275-292.

Karacan, H. (2018). Beşinci sınıf sosyal bilgiler dersi öğretim programı ve ders kitaplarında yer alan milli ve evrensel değerlerin analizi. Journal of Innovative Research in Social Studies, 1(1), 1- 10.

Karagözoğlu, N. (2020). Sosyal bilgiler ders kitaplarının değerlendirilmesi. İKSAD.

Keskin, Y. \& Yaman, E. (2014). İlköğretim sosyal bilgiler programı ve ders kitaplarında yeni bir paradigma: Çokkültürlü eğitim. Turkish Studies - International Periodical For The Languages, Literature and History of Turkish or Turkic, 9(2), 933-960.

Kirkit, M. (2019). Sosyal bilimler disiplinlerinin sosyal bilgiler programlarına ve ders kitaplarına yansıma durumları. [Yayımlanmamış Yüksek Lisans Tezi, Gaziantep Üniversitesi Eğitim Bilimleri Enstitüsü], YÖK Ulusal Tez Merkezi Veri Tabanı.

Köroğlu, C. Z., \& Köroğlu, M. A. (2016). Bilim kavramının gelişimi ve günümüz sosyal bilimleri üzerine. Pamukkale Üniversitesi Sosyal Bilimler Enstitüsü Dergisi, 25, 1-15.

Kuş, Z., Merey, Z. \& Karatekin, K. (2013). İlköğretim 4. ve 5. sınıf sosyal bilgiler ders kitaplarında yer alan değerler. Değerler Ĕgitimi Dergisi, 11(25), 183-214.

Küçükali, R., \& Akbaş, H. (2015). Eleştirel düşüncenin bilimlerin gelişmesine katkıları. Atatürk Üniversitesi Sosyal Bilimler Enstitüsü Dergisi, 19(3), 1-10.

Learner, A. (2020, 12 23). Dealing withcontroversial issues/ issues in social studies video:allgradelevels. AnnenbergLearner. $\quad$ https://www.learner.org/series/social-studies-in-action-a-teaching-practiceslibrary-k-12/dealing-with-controversial-issues/.

Lockwood, A. L. (2020, 12 26). Controversial issues:the teacher's crucial role. NCSS: http://www.socialstudies.org/sites/default/files/publications/se/6001/600105.html. 
Manitoba, E. (2006). Dealing with controversial lssues. https://www.edu.gov.mb.ca: https://www.edu.gov.mb.ca/k12/cur/socstud/frame_found_sr2/tns/tn-34.pdf.

MEB. (2018). Sosyal bilgiler dersi ögretim programı. MEB TTKB.

Miles, M. B., \& Huberman, A. M. (1994). An expanded sourcebook: Qualitative data analysis. SAGE Publications Inc.

National Council for the Social Studies (NCSS) (2007). Academic freedom and the social studies teacher, Social Education 74(6), 334-335. https://www.socialstudies.org/system/files/publications/articles/se 740610334.pdf.

Özdemir, Ç., \& Arslangilay, S. (2017). Ĕ̈itim bilimine giriş (4. b.). Pegem Akademi.

Öztürk, D. (2017). Sosyal bilgiler ögretmenlerinin tartışmalı konuların ögretimine ilişkin görüş ve uygulamaları. [Yayınlanmamış Doktora Tezi, Kastamonu Üniversitesi Sosyal Bilimleri Enstitüsü], YÖK Ulusal Tez Merkezi Veri Tabanı.

Pace, D. (2003). Controlled fission: teaching supercharged subjects. College Teaching Journal Artıcle, 51(2), 4245.

Pehlivan, A. \& Kolaç, E. (2016). Açık-Örgün eğitim sosyal bilgiler ders kitapları ve öğretim programında somut olmayan kültürel miras ögeleri. Turkish Studies, 11(19), 655-670.

Rossi, J. A. (1996). Creating strategies and conditions for civil discourse about controversial 1ssues. Social Education-ERIC, 60(1), 15-21.

Safran, M. (2012). Sosyal bilgiler ögrretimi (2. b.). Pegem Akademi.

Soley, M. (1996). If 1t's controversial, why teach 1t? National Council for the Social Studies-Social Education, 60(1), 9-14.

Stradling, R. (1984). The teaching of controversial issues: an evaluation. Educational review, 36(2), 121-129.

Şahin, E. (2018). Ortaokul ve imam hatip ortaokulu sosyal bilgiler 5 ders kitabl. Anadol.

Şişman, M. (2018). Eğitime giriş (18. b.). Pegem Akademi.

Tatar, Ş. (2018). İhmal edilen eğitim programında tartışmalı konuların ilk ve ortaokul ögretim programları bağlamında incelenmesi. [Yayımlanmamış Doktora Tezi, Anadolu Üniversitesi Eğitim Bilimleri Enstitüsü], YÖK Ulusal Tez Merkezi Veri Tabanı.

Tatar, Ş., \& Adıgüzel, O. C. (2019). Türkiye'de tartışmalı ve sosyobilimsel konular üzerine yazılan lisansüstü tezlerin eğitim bilimleri perspektifinden incelenmesi. Eskişehir Osmangazi Üniversitesi Sosyal Bilimler Dergisi, 20, $305-325$.

TDK, (2017) Online sözlük. http://www.tdk.gov.tr.

Tuncer, H. (2018). Sosyal bilgiler öğretmen adaylarının tartışmalı konuların öğretimine ilișkin görüşlerinin incelenmesi. [Yayımlanmamış Yüksek Lisans Tezi, Elazığ Üniversitesi Eğitim Bilimleri Enstitüsü], YÖK Ulusal Tez Merkezi Veri Tabanı.

White, M. D., \& Marsh, E. (2006). Content analysis: a flexible methodology. Library trends 55(1), 22-45.

Yazıcı, S. \& Seçgin, F., (2010). Tartışmalı konular ve öğretimine ilişkin bir çalışma. Uluslararası Sosyal Araştırmalar Dergisi, 3(12), 488-501.

Yılar, M. B. \& Çam, İ. D. (2020). 20. ve 21. Yüzyılın başlarına ait ders kitaplarında vergi: karşılaştırmalı bir değerlendirme. Sosyal Bilimler Araştırmaları Dergisi, 15(2), 503-514.

Yıldırım, A., \& Şimşek, H. (2008). Nitel araştırma yöntemleri (6. b.). Seçkin.

Yılmaz, F. G., Bayraktar, H., Özden, M. K., Akpınar, M., \& Evin, Ö. (2018). Ortaokul ve imam hatip ortaokulu sosyal bilgiler 6 ders kitabı. MEB.

Yılmaz, K. (2012). Tartışmalı ve tabu konuların incelenmesi: Sosyal bilgiler öğretmenlerinin görüşleri. Mustafa Kemal Üniversitesi Sosyal Bilimler Enstitüsü Dergisi, 9(18), 201-225. 
Yücel, A. G. (2018). Sosyal bilgiler öğretmen adaylarının eleştirel düşünme düzeylerinin gelişsiminde tartışmalı konuların etkisi. [Yayımlanmamış Yüksek Lisans Tezi, Nevş̧ehir Hacı Bektaşi Veli Üniversitesi Sosyal Bilimler Enstitüsü], YÖK Ulusal Tez Merkezi Veri Tabanı. 


\title{
EXTENDED ABSTRACT
}

\author{
The Review of Some Controversial Issues In Socual Studies Textbooks
}

\section{Introduction}

The controversial subjects are issues that cause disagreements and conflicts that arise due to differences in individuals' thoughts and opinions (Manitoba, 2006). Controversial or controversial issues are those that distract the society from consensus and divide society based on thought, and reveal irreconcilable arguments formed by different groups (Jofre, Kolstrein, Gianella, \& Iglesias, 2015). The paper published by the United States National Council of Social Studies NCSS (2007) supported the teaching of controversial issues and included the following views:

"Controversial issues should be discussed in the classroom without the assumption that the topic of discussion has been resolved in advance, or without assuming that there is only one correct perspective and answer regarding the issue. Social studies teachers should approach such issues with a critical point of view and enable students to confront various ideas even if they differ from their own" (cited in Yilmaz, 2012, p. 203).

Therefore, it can be claimed that controversial subjects are also important for social studies courses. Instruction of controversial issues to students should be handled more effectively in the classroom environment in social studies lessons, and should be brought to the classroom in a planned and prepared way if necessary. The controversial topics covered in this way can contribute to the actualization of the achievements and targeted goals in the Social Studies curriculum. It can also contribute to the student's skills such as problem solving, creative thinking, reflective thinking, critical thinking, and decision-making (Avaroğulları, 2015). Based on this point of view, this study aims to analyze and review controversial subject titles such as "Science and its subtitle: Extinct Species, Biofuels, Climate Change. Water Problem, Genetically Modified Organisms (GMO)", included within 5th, 6th and 7th grade social studies textbooks in the 2018/2019 academic year approved by the Ministry of National Education by looking at their content and reveal how the reflections of the controversial subject headings are, the learning areas they take place, unit, topic analysis, frequency of use and disadvantages. The following questions were attempted to be answered in the study:

1- How is the distribution of controversial topics compared to the units in 5th, 6th and 7th grade social studies textbooks which involve science, extinction species, biofuels, climate change, water shortage, genetically modified organisms?

2- What is the frequency and reflection of the controversial / controversial topics in the units in 5th, 6th and 7th grade social studies textbooks which involve science, extinction species, biofuels, climate change, water shortage, genetically modified organisms? What is the in the classroom textbooks $\mathrm{s}$

3- How is the distribution of controversial topics in the learning areas and class levels in 5th, 6th and 7th grade social studies textbooks which involve science, extinction species, biofuels, climate change, water shortage, genetically modified organisms? 


\section{Method}

Documentation analysis was applied on the controversial topics within the scope of the research. Later, the descriptively analyzed and interpreted data were subjected to content analysis. Document analysis, which is frequently used in qualitative research, is a qualitative data collection technique that enables the researcher to reach the information or data they need without using practice-based methods such as observation and interview (Y1ldirım \& Şimşek, 2008). Yıldırım and Şimşek (2008) explained the stages of document analysis as access to the documents, checking the authenticity, understanding the documents, analyzing the data, and using the data. Content analysis, one of the qualitative research methods, is defined as a flexible research method, a systematic approach used to analyze the data obtained during the research or documents such as books, documents, visuals (White \& Marsh, 2006). The stages of content analysis are coding of data, finding themes, organizing codes and themes, defining and interpreting the findings (Yıldırım \& Şimşek, 2008, p. 228-239). In this context, within the framework of research questions, science and its subheadings were examined by theming them in each learning area whose codes were examined and in the topics in the textbooks. In each stage, the categories were handled separately, frequencies were created and it was attempted to be supported by quantitative data. The data encoded in the title of science -for example in the Individual and Society theme- were analyzed, interpreted, and the findings were revealed regarding to how issues were addressed, and their presence in the content. As stated in the validity and reliability phase, it was also aimed to present the research in a more objective framework by asking the field expert researchers to re-analyze the data in the same process.

\section{Results}

Within the scope of the research, when the social studies textbooks of the 5th, 6th and 7th grades were examined, it was observed that they consisted of a book written by a private publishing house on behalf of the Ministry of National Education in the 5th grade, and a book directly prepared by the Ministry of Education in the 6th and 7th grades. It is possible to see that the changes in the renewed 2018 curriculum are reflected in the books. In addition, while various unit titles of each learning area were given in the old books, it was observed that each of the learning areas was a unit title in the new books.

According to the findings in the 5th, 6th and 7th gaders' social studies books in 2018/2019 which involve "Science" and its subtitles "Extinct Species, Biofuels, Climate Change, Water Distress, Genetically Modified Organisms" discussed in this study, it is possible to claim that the developmental and learning levels of primary school students are generally taken into consideration. A number of visuals, questions, reading texts, different types of writing and directions were used to effectively include some of the controversial topics in the content. However, some reasons such as the intensity of the content, the fact that the acquisitions are at the basis of the teaching process, the students' orientation to exam-orientedness and time management may negatively affect the teaching of controversial subjects sufficiently and effectively in the course process.

In the results obtained within the framework of the research problems, science -one of the controversial topics- is reflected at most in the content of the 5th grade social studies textbook in the learning area of Science, Technology and Society. It is possible to observe that the controversial topic is reflected in the content of the questions in the preparation phase of the 
lesson, the topics in which scientists and scientific ethics are explained. When looking at other learning areas, it can be claimed that the concept of science is included in each learning area and reflected in the subject headings. Following the concept of science, the most reflected topic in the content was water shortage. It can be expressed that the concepts of climate change, GMOs and extinct species are reflected in the content, even if at a small level. However, it can be argued that the subject of biofuel was not addressed in the 5th grade textbook.

In the results obtained within the framework of the research problems, science -one of the controversial subject titles- is reflected at most in the content of the 6th grade social studies textbook in the learning area of Science, Technology and Society. It is possible to observe that the controversial topic is reflected in the content of the questions in preparation for the lesson, in the titles of social sciences and society, and reality in my dreams. When looking at other learning areas, it can be claimed that the concept of science is included in each learning area and reflected in the subject headings. Following the concept of science, the most reflected topic in the content was water shortage. It can be expressed that the concepts of climate change, biofuels and extinct species are reflected in the content, even if at a small extent. However, it can be argued that GMO was not mentioned in the 6th grade.

According to the results of the research, it can be claimed that the controversial topic science- was directly reflected as a concept in the content of the 5th, 6th and 7th grade social studies textbooks, but it was observed that other titles were most of the time reflected in indirect expressions.

Findings and comments regarding to textbooks that have been examined and analyzed within the scope of the research are explained as above. The teaching of each of the controversial topics in terms of social studies can be effective in the actualization of values, skills and program goals. Öztürk (2017) expressed that including controversial topics, especially in social studies courses, would help students to gain lots of qualities. Öztürk (2017) explained the important reasons for the discussion of controversial topics in the classroom as follows:

1. Preparing students for the role of citizens in a pluralistic democracy.

2. To develop critical thinking skills.

3. To improve interpersonal communication skills.

"International Journal of New Approaches in Social Studies - IJONASS" is licensed under a Creative Commons Attribution-NonCommercial-ShareAlike 4.0 International License. 